\title{
REVIEW
}

\section{Biological and clinical impact of imbalanced progesterone receptor isoform ratios in breast cancer}

\author{
Caroline A Lamb1, Victoria T Fabris', Britta M Jacobsen², Alfredo Molinolo³ and Claudia Lanari1 \\ IInstituto de Biología y Medicina Experimental (IBYME), CONICET, Buenos Aires, Argentina \\ 2University of Colorado Anschutz Medical Campus, Aurora, Colorado, USA \\ ${ }^{3}$ Moore's Cancer Center, UCSD, La Jolla, California, USA \\ Correspondence should be addressed to C Lanari: lanari.claudia@gmail.com
}

\begin{abstract}
There is a consensus that progestins and thus their cognate receptor molecules, the progesterone receptors (PRs), are essential in the development of the adult mammary gland and regulators of proliferation and lactation. However, a role for natural progestins in breast carcinogenesis remains poorly understood. A hint to that possible role came from studies in which the synthetic progestin medroxyprogesterone acetate was associated with an increased breast cancer risk in women under hormone replacement therapy. However, progestins have also been used for breast cancer treatment and to inhibit the growth of several experimental breast cancer models. More recently, PRs have been shown to be regulators of estrogen receptor signaling. With all this information, the question is how can we target $P R$, and if so, which patients may benefit from such an approach? PRs are not single unique molecules. Two main PR isoforms have been characterized, PRA and PRB, which exert different functions and the relative abundance of one isoform with respect to the other determines the response of PR agonists and antagonists. Immunohistochemistry with standard antibodies against PR do not discriminate between isoforms. In this review, we summarize the current knowledge on the expression of both PR isoforms in mammary glands, in experimental models of breast cancer and in breast cancer patients, to better understand how the PRA/PRB ratio can be exploited therapeutically to design personalized therapeutic strategies.
\end{abstract}

\author{
Key Words \\ - progesterone receptor \\ isoforms \\ - progestins \\ - antiprogestins \\ - breast cancer \\ - patient-derived xenografts \\ - PR isoform ratio \\ - prognostic markers \\ - in vivo breast cancer models
}

\section{Introduction}

Nuclear estrogen receptors alpha (ER $\alpha)$ represent almost the first molecular targets used for breast cancer treatment, and two-thirds of these patients are treated with an endocrine therapy. Nuclear progesterone receptors (PRs) on the other hand, have been evaluated as surrogate markers of ERo integrity and functionality. There is nowadays emerging interest in understanding the interplay between the different members of the nuclear hormone receptor family and their role in tumor growth.

PRs are members of the nuclear steroid family of receptors, together with ER, androgen (AR), glucocorticoid (GR)/mineralocorticoid (MR) receptors and other less related molecules such as thyroid receptors, retinoic acid and orphan receptors (reviewed in Grimm et al. 2016). 
They are ligand-activated transcription factors that can also act through ligand-independent mechanisms. Receptors other than the classical nuclear steroid receptor family are also involved in generating progesterone (P4)mediated effects (reviewed in Mueck et al. 2014).

\section{PR isoforms}

The human PR gene consists of eight coding exons separated by seven non-coding introns. There are mainly two mRNA transcripts controlled by two different promoters, each one encoding a different protein. The mRNA regulated by the distal promoter encodes the fulllength PR named PRB (116kDa; 933 amino acids (aa)); the one regulated by the proximal promoter encodes the truncated version, named PRA $(94 \mathrm{kDa})$, which lacks the first 164 aa starting its translation in the methionine 165 (reviewed in Abdel-Hafiz \& Horwitz 2014). These two isoforms were originally described in the chick oviduct. Other mRNA PR variants with different deleted exons were detected in breast cancer tissues and cell lines (Cork et al. 2008). However, how these mRNAs influence PR signaling and if they are translated into functional proteins remains to be established. A third predicted truncated PR isoform, named PRC $(60 \mathrm{kDa})$, results from an alternative translation site starting at methionine 595 . This form should retain the ability to bind the ligand, but not DNA. It was first described in T47D cells (Wei et al. 1990), and it has been suggested that it may play a role in labor (Condon et al. 2006) where high PRC levels are associated with an increase in the PRA to PRB ratio (Renthal et al. 2015). A $78 \mathrm{kDa}$ protein was also detected in breast cancer samples using PR antibodies (Graham et al. 1995). Since it is not reactive with an antibody that recognizes only $\mathrm{PRB}$, it has been originally proposed as a PRA variant (Yeates et al. 1998).

In the next part of this review, we will focus on the two main PR isoforms, PRB and PRA, and the impact that the different PR isoform ratios might have on breast cancer progression.

\section{PRA and PRB isoforms: localization, genomic and non-genomic effects}

PRB isoforms have an amino terminal region named $A / B$, with a high degree of variability among the different nuclear receptors. Two transactivation domains: AF1 (aa 456-546) and AF3 (aa 1-164) located in this region participate in coactivator recruitment (Dobson et al. 1989). In addition, an inhibitory domain is involved in corepressor recruitment (Hovland et al. 1998). The DNAbinding domain consists of 78-80 aa and is composed of two type II zinc finger structures involved in the binding to specific cis-acting DNA sequences, the PR elements (PRE). The ligand-binding domain is located at the carboxy terminal end of the PR. It contains a third transactivation domain (AF-2) required for hormonedependent coactivator recruitment, dimerization and interaction with chaperone proteins in the inactive state (reviewed in Hilton et al. 2015).

PRA differs from PRB in the lack of the AF3 transactivation site, located in the B-Upstream Segment (BUS) of PRB (Sartorius et al. 1994b). Similar affinities of PRA and $\mathrm{PRB}$ for the natural ligands and medroxyprogesterone acetate (MPA) have been reported (Ghatge et al. 2005); however, this is not valid for the progestins levonorgestrel or gestodene (Schoonen et al. 1998). After ligand activation, PR isoforms dimerize forming homo- or heterodimers. There is still no consensus on whether PR dimerization is necessary for binding to palindromic DNA sequences. A different model proposes that the activation of single monomers, which bind to PRE half sites (Jacobsen et al. 2009), might be thermodynamically favored (Heneghan et al. 2005). Many of the endogenous PR-binding sites detected by chromatin immunoprecipitation sequencing contain these PRE half sites (Ballare et al. 2013). More recently, it has been shown that in cells transfected with $\mathrm{PRB}$, ligand activation promotes tetramerization of PR in a DNA-independent manner (Presman et al. 2016).

Another level of complexity is the fact that P4 may also elicit rapid non-genomic effects activating cytoplasmic signaling pathways (reviewed in Boonyaratanakornkit et al. 2018). These effects are mediated by PRB, as this isoform shuttles between nuclear and cytoplasmic compartments whereas, PRA is mainly localized in the nucleus (GuiochonMantel et al. 1994, Boonyaratanakornkit et al. 2008). In pathological contexts, the abnormal presence of cytosolic PRA may interfere with normal signaling.

PRA may also act as a ligand-dependent transdominant repressor of other steroid receptors including PRB, ER $\alpha, A R, M R$ and GR (reviewed in Chabbert-Buffet et al. 2005), but this effect may not be so relevant under physiological conditions (Scarpin et al. 2009). In most cases, PRB functions as an activator of progesteroneresponsive genes in conditions in which PRAs are transcriptionally inactive (reviewed in Jacobsen \& Horwitz 2012). Notwithstanding, genes regulated exclusively by PRA have been reported (Richer et al. 2002, Jacobsen et al. 2005). PRB competes with $\mathrm{ER} \alpha$ for the same coactivators (McDonnell \& Goldman 1994, Wen et al. 1994). 
This coactivator squelching represents another mechanism through which progestins inhibit estrogen action. More recently, a rewiring of ER $\alpha$ and PR after progestin treatment was proposed to explain the inhibitory effects of progestins on breast cancer cell proliferation (Mohammed et al. 2015).

After ligand binding, PR aggregates in nuclear foci where the transcriptional activity takes place (ArnettMansfield et al.2007). The activated PR exerts their genomic effects by binding either to PRE directly at the promoter of target genes or can be tethered to other transcription factors, thus regulating the expression of genes that lack PRE sites. PR isoform-mediated transcription has been reviewed in depth elsewhere (Jacobsen \& Horwitz 2012). Post-translational modifications can modulate PR transcriptional activity. These include phosphorylations, acetylations, ubiquitinations, glycosylations and SUMOylations in serine and lysine residues located in the amino terminal end. The functional effects of these modifications are related to several factors such as modulation of the transcriptional activation or repression, DNA binding, cofactor recruitment, receptor turnover and changes in hormone responsiveness (reviewed in Qiu \& Lange 2003, Abdel-Hafiz \& Horwitz 2014, Diep et al. 2015). Several studies have suggested that, upon ligand binding, PRA is rapidly SUMOylated, while PRB becomes deSUMOylated. SUMOylation is a stabilizing modification and thus PRA results in a more stable isoform relative to PRB (Daniel et al. 2007). This biochemical difference in isoform SUMOylation, together with the increased turnover of PRB due to mitogen-activated protein kinasedependent phosphorylation of serine 294 (Shen et al. 2001, Faivre \& Lange 2007) may explain the PRA predominance observed in many human data sets reviewed herein.

\section{Methods to determine PR isoform expression}

PR isoform expression has been determined using PCR, western blots (WB) or immunohistochemistry (IHC)/immunofluorescence (IF) techniques. A critical issue in PR isoform mRNA detection is the correct primer design. Errors were detected in several studies by Aupperlee et al. (2005a). The levels of PRA are calculated by subtracting PRB from total PR adding a further degree of complexity.

Currently, WB is the most reliable method to evaluate $\mathrm{PR}$ isoforms since the ratio can be calculated in the same assay using one antibody. Notwithstanding, there are several limitations: (a) PRB splice variants with similar molecular weight (MW) to PRA might interfere with the
PRA band; (b) antibodies should have equal affinities for both denatured PR proteins and (c) WB is not in the routine practice in the clinic.

The detection of PR isoforms by IHC or IF is still controversial. A list of antibodies that did not recognize PRB by IHC in gelatin-embedded cells uniquely expressing PRB has been reported (Mote et al. 2001). A PRA-specific antibody is offered by Leica, a Novocastra antibody known as clone 16 or 312 . The FDA approved this antibody to detect total PR in human tissue; however, the antibody is commercialized as a specific PRA antibody. Following these assumptions, many investigators have published results describing and quantifying PR isoform expression in different tissues using IHC (Kreizman-Shefer et al. 2014, Bartosch et al. 2015, Bonneterre et al. 2016). In xenografts, using cell lines modified to express either PRA or PRB, this antibody proved to be excellent to recognize both PR isoforms by IHC (Fabris et al. 2017).

\section{PR isoforms in the mammary gland}

PRA and PRB expression ratio may change in the different reproductive tissues. Even in the same organ, the PR ratio may differ according to the developmental stage or hormonal status (reviewed in Patel et al. 2015, Hilton et al. 2018).

Both PR isoforms are expressed in the mammary gland of most of the species studied. Equimolar ratios have been reported in human breast (Mote et al. 2002), higher levels of PRA than PRB (3:1) in mouse mammary glands (Schneider et al. 1991), and a single PRB isoform in the rabbit. Table 1 depicts in detail the PRA/PRB changes during the different stages of mammary gland development in different species.

\section{PR isoforms in genetically modified mice}

$\mathrm{PRB}$ is required for mammary morphogenesis during pregnancy (reviewed in Conneely et al. 2003). PR-knockout (KO) mice show decreased branching and lobuloalveolar differentiation. PRA-KO mice are infertile, but the mammary gland develops normally in response to P4, indicating that PRB is necessary and sufficient to induce mammary gland proliferation and differentiation during pregnancy. PRB-KO mice are fertile but the mammary gland is unable to differentiate (reviewed in Conneely et al. 2003). Conversely, transgenic mice overexpressing PRA show ductal hyperplasia (Shyamala et al. 2000) that was reversed by antiestrogen but not with antiprogestin treatment (Sampayo et al. 2013) and, mice overexpressing 


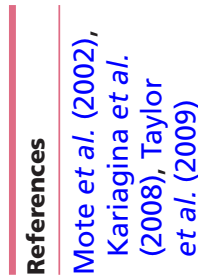

暲皇

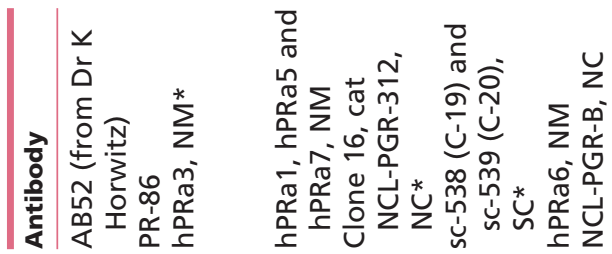

$\bar{z} \quad \bar{z}$

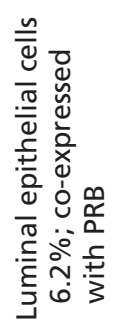

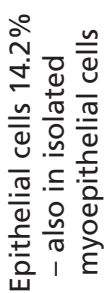

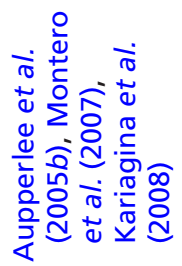

$\stackrel{\underline{u}}{\underline{\underline{I}}}$

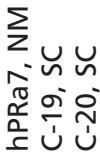

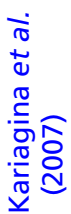

느

定 $\sum^{\infty}$

筑

₹

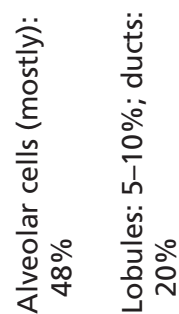

쓰

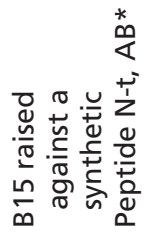

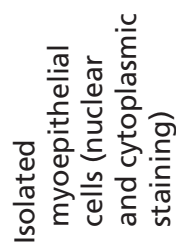

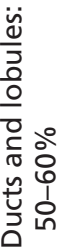
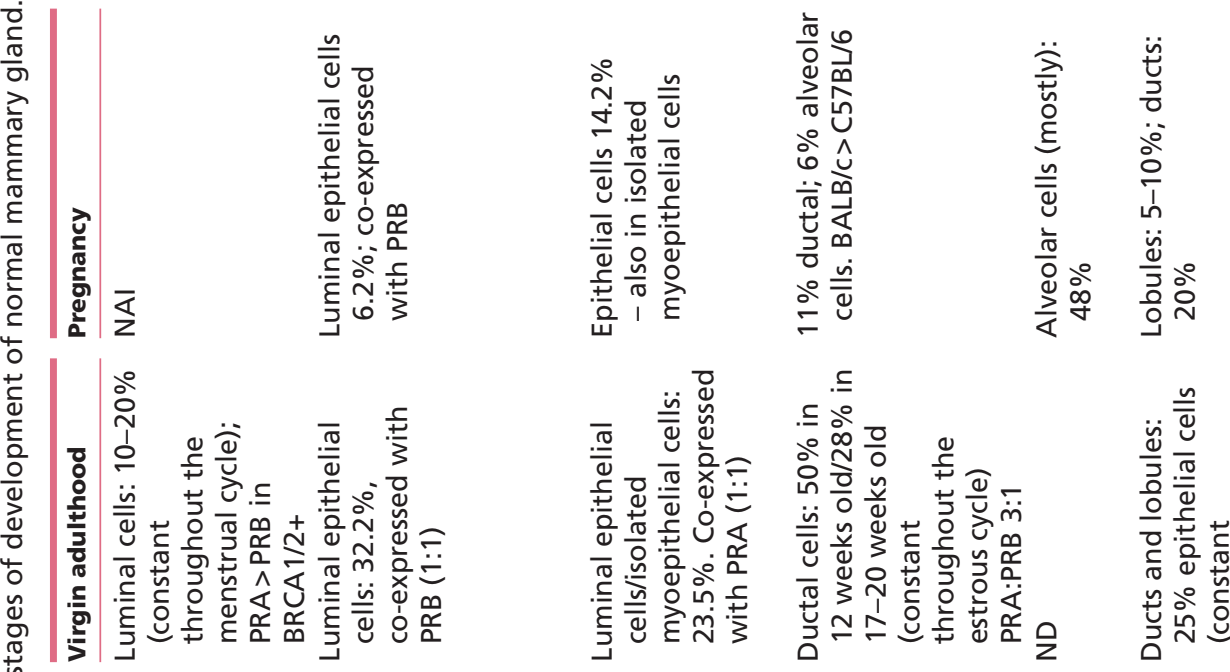

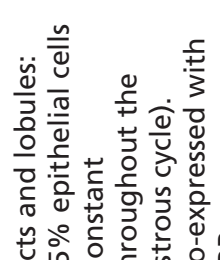

4

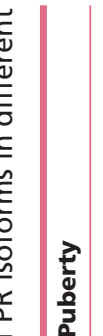

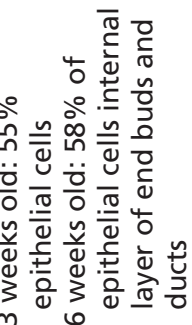
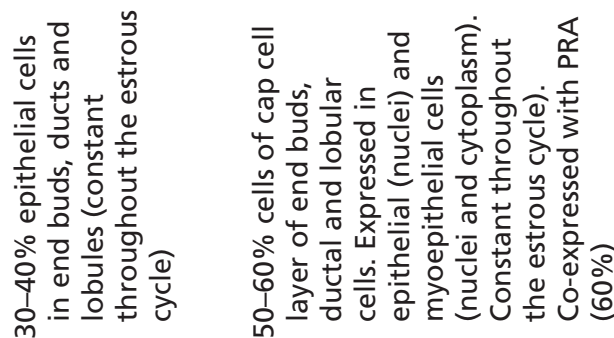

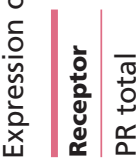

$\bar{s}$

$\bar{z}$

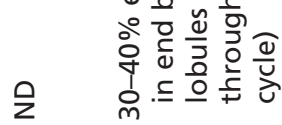

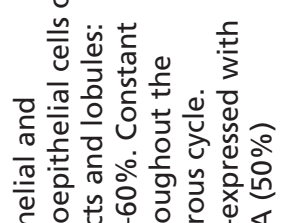

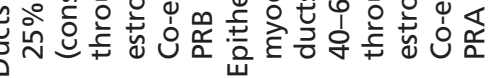

总

压

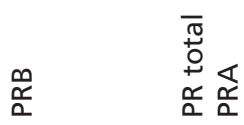

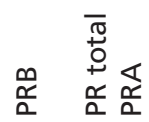

$\stackrel{m}{\frac{⿱ 乛 龰}{\alpha}}$ 


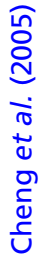

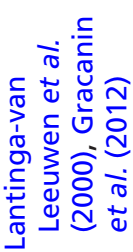

$\stackrel{\cup}{\underline{I}}$

논

哟

$\sum^{\infty}$

z $\quad u$

z

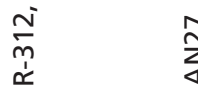

文

ن̀

$\stackrel{\stackrel{1}{z}}{z}$

은

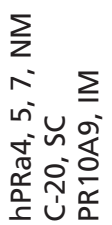
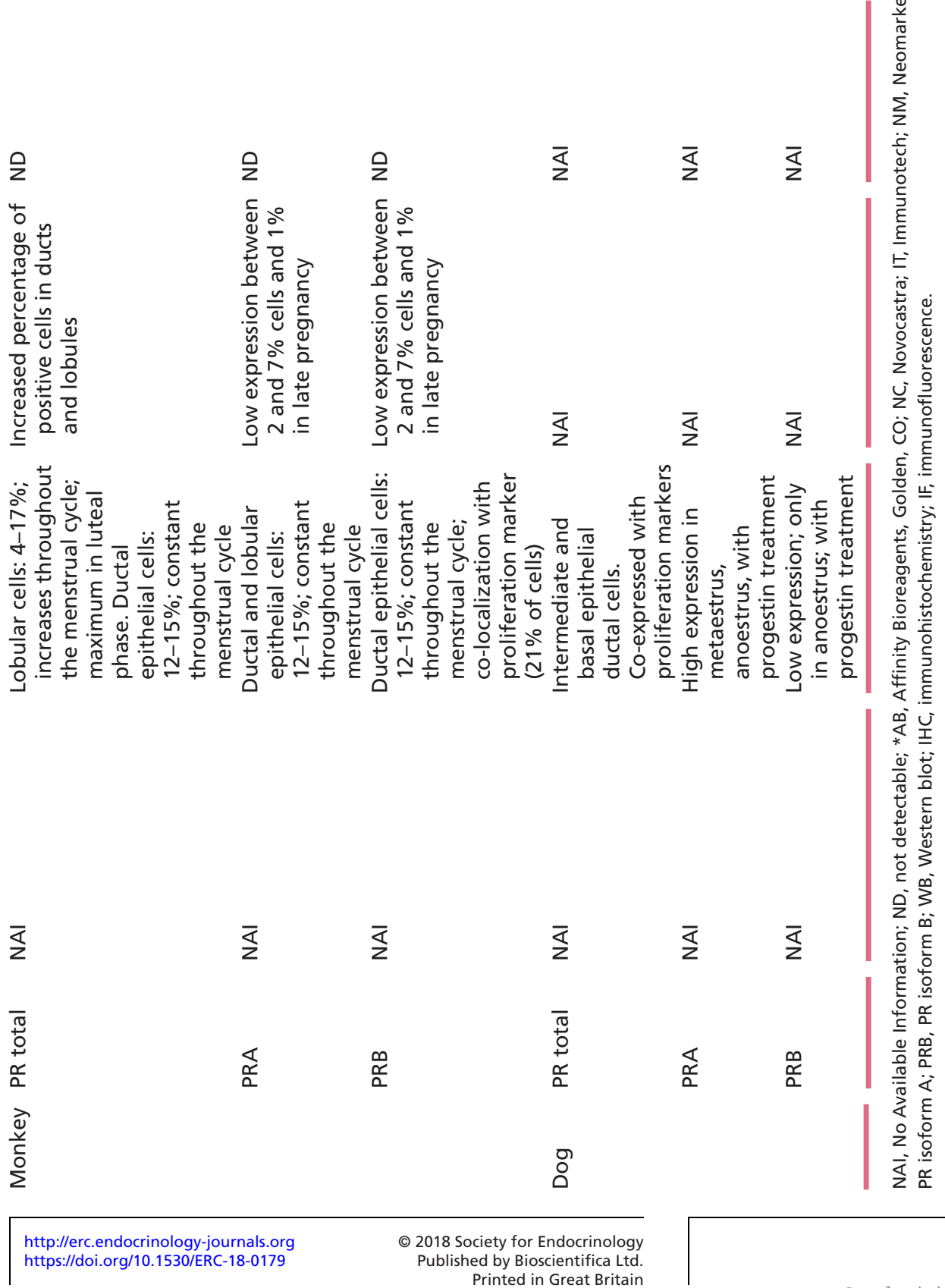
PRB did not show ductal elongation and no ends buds were developed (Shyamala et al. 2000).

Transgenic C/EBPB mice showed an altered pattern of PR isoform expression (Grimm \& Rosen 2003), suggesting that C/EBPB plays a role in the regulation of PR. PR, but not $E R \alpha$, are also overexpressed in the mammary epithelial cells of Brca1/p53-deficient mice because of a defect in PR degradation (Poole et al. 2006), mirroring the data of human mammary glands from $B R C A+$ patients showing increased levels of PRA/PRB (King et al. 2004). Furthermore, treatment of Brca1/p53-deficient mice with the PR antagonist, mifepristone (MFP; RU-486) prevented mammary tumorigenesis (Poole et al. 2006).

\section{PR isoforms in human breast cancer cell lines}

PR isoform expression and PR isoform ratio differentially affect breast cancer progression. Although controversial, in vitro (Lin et al. 1999, Khan et al. 2012, Wargon et al. 2015, Diep et al. 2016) and in vivo (Sartorius et al. 2003, Wargon et al. 2015) studies with breast cancer cell lines support this notion.

The in vitro evidence comes from studies using: (a) T47D cells with constitutive expression of both PR isoforms or modified to alter the PR isoform ratio (McGowan \& Clarke 1999, Jacobsen et al. 2002, McFall et al. 2015, Wargon et al. 2015) or engineered to overexpress only PRA (T47D-YA) or PRB (T47D-YB) (Sartorius et al. 1994a); (b) MCF-7 cells in which endogenous PR is expressed after estradiol treatment or modified to express exogenous PR (Boonyaratanakornkit et al. 2001, McGowan et al. 2007); (c) ZR-75-1 cells in which PRB is the prevalent isoform (Diep et al. 2016); (d) IBH-6 cells that express low ER $\alpha$ and PR levels (Vazquez et al. 2004) and have been modified to overexpress PRA or PRB (Wargon et al. 2015); (e) MDA-MB-231, which are claudin low triple-negative cells, modified to express both PR isoforms or only PRB (Lin et al. 1999, 2000) or to conditionally express PRA, PRB or both isoforms (Khan et al. 2012, Bellance et al. 2013) and (f) BT-474 cells modified to express higher PRB levels as compared to the PRA isoform (Wu et al. 2004).

Experimental evidence points to PRB as the more proliferative isoform (Faivre et al. 2008) (reviewed in Lange et al. 2008). Progestins induce cell cycle progression in T47D-YB cells stably expressing PRB (Skildum et al. 2005). However, a biphasic effect of progestins has been reported in T47D cells showing a late inhibitory effect preceded by an increase in cell cycle progression (Musgrove et al. 1991). Conversely, in T47D cells with inducible PRA, there was no significant change in cell proliferation but displayed reduced adherence to plastic, suggesting that increased PRA expression, may play a role in loss of adhesion observed in cancers (McGowan \& Clarke 1999, Graham et al. 2005) and an increased ability to invade stromal tissue (McGowan et al. 2004).

The experimental data regarding the role of $P R$ isoforms in tumor invasiveness and/or aggressiveness in vitro is still controversial. In some experimental models, PRA+ cells exhibit a more invasive and aggressive behavior (McGowan et al. 2003, Jacobsen et al. 2005), whereas in others, induction of PRB leads to an increase in cell migration (Ibrahim et al. 2008, Bellance et al. 2013).

The genomics of P4-induced effects on gene transcription mediated by PR isoforms has been studied in the T47D-YA/-YB model (Richer et al. 2002, Tung et al. 2006), in the MDA-MB-231 cells transfected with total PR or PRB (Leo \& Lin 2008) or in the inducible systems (Graham et al. 2005, Jacobsen et al. 2005, Khan et al. 2012). In this review, we will focus on data obtained in vivo.

\section{PR isoforms in experimental tumor growth}

\section{Mouse mammary carcinomas}

There are few mouse mammary carcinoma models that express ER $\alpha$ and PR. MMTV-induced tumors were studied at a time that PR was detected by ligand-binding techniques and, to the best of our knowledge, no information has been reported regarding the prevailing PR isoforms in these models.

Our group developed MPA-induced mammary carcinomas, which expressed high levels of ER $\alpha$ and PR (reviewed in Lanari et al. 2009). With time, several different tumor variants arose which were classified according to their response to antiprogestin treatment. PR isoform expression revealed that responsive carcinomas had high PRA/PRB ratios while resistant carcinomas displayed the opposite ratio (Wargon et al. 2015). Two types of resistant variants were characterized: constitutive and acquired. The former carried a specific PRA promoter methylation and, upon demethylation, PRA expression and antiprogestin responsiveness were restored (Wargon et al. 2011). In acquired resistant variants, continuous antiprogestin treatment induced a decrease in PRA expression and estrogen or tamoxifen treatment restored antiprogestin responsiveness by increasing PRA expression, thus changing the PRA/PRB ratio (Wargon et al. 2009).

A large number of genetically engineered mice have also been developed in an attempt to model endocrineresponsive human breast cancer; however, few ER+ 
luminal mammary carcinomas have been generated (reviewed in Dabydeen \& Furth 2014). PR isoforms were only briefly mentioned. In the Wnt1 transgenic model, variable levels of PRB and PRA were observed among the different tumors (Zhang et al. 2005); whereas in the two cases shown of the Stat1 KO model, high levels of both PRA and PRB were observed in WB, although they were not quantified (Chan et al. 2012).

\section{Rat mammary carcinomas}

To the best of our knowledge, there are no available data on PR isoform expression in rat mammary carcinomas.

\section{Feline mammary carcinomas}

The percentage of total $\mathrm{PR}+$ cells increases in feline invasive mammary carcinomas as compared to normal mammary gland (67\% vs 15\%, respectively) (Millanta et al. 2005) and similar levels of PRA and PRB were observed by WB in mammary carcinomas (Gracanin et al. 2012).

\section{Canine mammary carcinomas}

In PR+ canine mammary carcinomas, higher levels of PRA than those of PRB were observed (Gracanin et al. 2012, Guil-Luna et al. 2014) and the antiprogestin aglepristone inhibited tumor growth (Guil-Luna et al. 2011). More recently, tumor samples excised before and after aglepristone treatment were analyzed for PR mRNA and Ki67 antigen labeling (Guil-Luna et al. 2017). In aglepristone-treated PRA+ tumors, both total PR and PRA mRNA expression levels decreased as well as the proliferation index, suggesting that PRA mediates the inhibitory effect.

\section{Cell line-derived xenograft models}

The PRA/PRB ratios in different breast cancer cell linederived xenograft models are depicted in Table 2. T47D xenografts are strictly $17-\beta$-estradiol (E2)-dependent for their in vivo growth. Bagatell et al. reported double bands for PRA and PRB using the PR MC243 antibody in WB (Bagatell et al. 2001), whereas Sartorius et al. showed increased PRB expression as compared with that of PRA in the T47D xenografts growing in nude female mice (Sartorius et al. 2003). We found similar levels of both PR isoforms, but occasionally there was an increase in PRB. T47D and T47D-YA tumors grow slower than the T47D-YB when inoculated into nude (Sartorius et al. 2003) or
NSG mice (Wargon et al. 2015). T47D-YA xenografts are tamoxifen and MFP sensitive while T47D-YB are resistant to both agents (Sartorius et al. 2003, Wargon et al. 2015). MPA induced only a slight increase in tumor growth of T47D xenografts; however, it did increase the expression of stem cell markers such as CK5 and BCL6 (Goodman et al. 2016). Others reported that P4 slightly decreased estrogen-induced tumor growth in MCF-7 and in T47D xenografts (el Etreby \& Liang 1998, Mohammed et al. 2015) although in the latter, the decrease in growth rate was only significant when P4 was administered together with tamoxifen.

More recently, Singhal et al. reported that in T47D xenografts, the antiprogestin telapristone (TLP) induced transient inhibition of tumor growth, while the combined administration together with tamoxifen induced an almost complete tumor regression (Singhal et al. 2016). A similar effect was obtained with two other antiprogestins: CDB 4453 and EC313 (Singhal et al. 2018). These results are in line with the inhibitory effect previously observed in T47D xenografts treated with MFP (Wargon et al. 2015).

P4 (pellet; $25 \mathrm{mg}$ ) inhibited the growth of MDA-MB-231 cells transfected with $\mathrm{PR}$ (ABC28 clone) inoculated into ovariectomized NOD/SCID mice. Overall the tumors were too small, and no metastases were observed in any of the groups (Lin et al. 2001). Recently, we found that tumor growth and metastases were lower in MDA-MB-231 cells stably transfected with PRB inoculated into NSG mice as compared to the control counterparts. However, while MPA inhibited lung metastasis, MFP induced an increase in the number and size of the metastatic foci (Lanari et al. 2016).

IBH-4, IBH-6 and IBH-7 are ER $\alpha+\mathrm{PR}+$ human breast cancer cell lines (Vazquez et al. 2004) that originate tumors when transplanted into nude mice (Bruzzone et al. 2009). IBH-4 and IBH-6 were able to grow without hormone supply and IBH-7 was strictly estrogen dependent (Bruzzone et al. 2009). Tumors express ER $\alpha$ and PR and although not quantified, higher levels of PRB than PRA were observed in WB (Bruzzone et al. 2009). MPA did not alter tumor growth; however, in the three cases the curves corresponding to MPA-treated mice showed a trend to decrease the growth rate as compared with their matched controls, either in the presence or absence of E2. Tamoxifen significantly inhibited the growth of IBH-4 and IBH-6 tumors.

IBH-6 tumors were not inhibited by antiprogestins such as MFP or TLP. However, these antiprogestins inhibited the growth of cells manipulated to overexpress PRA, whereas MFP stimulated those overexpressing PRB (Wargon et al. 2015). 
Table 2 PR isoform imbalance in cell line xenograft breast cancer models.

\begin{tabular}{|c|c|c|c|c|c|c|}
\hline Cell line/tumor & PRA/PRB ratio & Assay & Mice & Antibodies & $\begin{array}{l}\text { Effect of hormones/ } \\
\text { antagonists }\end{array}$ & References \\
\hline \multirow[t]{3}{*}{$\begin{array}{l}\text { T47D (ER+, PR+, } \\
\text { AR+, GR+ (low), } \\
\text { HER2-, P53 } \\
\text { mutation) }\end{array}$} & $\begin{array}{r}P R A=P^{P B} 1,2 \\
P R B>P^{1,2}{ }^{3}\end{array}$ & WB & $\begin{array}{l}\text { NSG } 1,6 \\
\text { SCID }^{2} \\
\text { Nu/nu } \\
3,4,5,7\end{array}$ & $\begin{array}{l}\text { MC243\#2; } \\
\text { AB-52* } \\
\text { B-30*3 } \\
\text { H-190 } \\
\text { (sC-7208, } \\
\text { SC€) or } \\
\text { Dako } 12941\end{array}$ & $\begin{array}{l}\text { MPA } \uparrow \text { tumor growth } 4 \text { and } \\
\text { stem cell markers } \\
\text { P4 } \downarrow \text { slightly E2-induced } \\
\text { tumor growth and } \\
\text { improved TAM-induced } \\
\text { inhibition } \\
\text { Antiprogestins (MFP1, } \\
\text { TLP } 1,7 \text { ) } \downarrow \text { tumor growth } \\
\text { Antiprogestins (CDB4453 } \\
\text { and EC313) } \downarrow \text { tumor } \\
\text { growth that is } \\
\text { potentiated by } \text { TAM }^{8}\end{array}$ & $\begin{array}{l}\text { 1: Wargon et al. } \\
\text { (2015); 2: Bagatell } \\
\text { et al. (2001); 3: } \\
\text { Sartorius et al. } \\
\text { (2003); 4: Liang et al. } \\
\text { (2007); 5: Goodman } \\
\text { et al. (2016); 6: } \\
\text { Mohammed et al. } \\
\text { (2015); 7: Singhal } \\
\text { et al. (2016); 8: } \\
\text { Singhal et al. (2018) }\end{array}$ \\
\hline & $\begin{array}{l}\text { T47D-YA } \\
\text { Only PRA }\end{array}$ & WB & $\begin{array}{l}n u / n u^{1} \\
\text { NSG }^{2}\end{array}$ & $\begin{array}{l}\text { AB-52; B-301; } \\
\text { H-190 (SC) } \\
\text { or Dako } \\
1294^{2}\end{array}$ & $\begin{array}{l}\downarrow \text { growth rate as } \\
\text { compared with }-\mathrm{YB}^{1,2} \text {; } \\
\text { inhibited by TAM } 1 \text { and } \\
\text { MFP2 }^{2}\end{array}$ & $\begin{array}{l}\text { 1: Sartorius et al. } \\
\text { (2003); 2: Wargon } \\
\text { et al. (2015) }\end{array}$ \\
\hline & $\begin{array}{l}\text { T47D-YB only } \\
\text { PRB }\end{array}$ & WB & $\begin{array}{l}n u / n u^{1} \\
\text { NSG }^{2}\end{array}$ & $\begin{array}{l}\mathrm{H}-190(\mathrm{SC}) \text { or } \\
\text { Dako } 1294\end{array}$ & $\begin{array}{l}\uparrow \text { growth rate as } \\
\text { compared with wt and - } \\
{\text { YA } 1,2 ; \mathrm{TAM}^{1} \text { and MFP2 }} \text { resistant }\end{array}$ & $\begin{array}{l}\text { 1: Sartorius et al. } \\
\text { (2003); 2: Wargon } \\
\text { et al. (2015) }\end{array}$ \\
\hline \multirow[t]{2}{*}{$\begin{array}{l}\text { MDA-MB-231 (ER-, } \\
\text { PR-, AR-, HER2-, } \\
\text { P53 mut) }\end{array}$} & $\begin{array}{l}\text { Transfection of } \\
\text { PRA/-B } \\
\text { ABC28 clone }\end{array}$ & NAI & SCID & $\mathrm{NAI}$ & P4 $\downarrow$ tumor growth & Lin et al. (2001) \\
\hline & PRB & WB & NSG & $\begin{array}{l}\mathrm{H}-190(\mathrm{SC})^{1,2} \\
\text { Clone } 16 \\
\text { (NC€)2; } \\
\text { Clone } 636 \\
(\mathrm{NC})^{2}\end{array}$ & $\begin{array}{l}\text { Fewer metastases than wt. } \\
\text { MPA } \downarrow \text { and MFP } \uparrow \text { lung } \\
\text { metastasis }{ }^{1}\end{array}$ & $\begin{array}{l}\text { 1: Lanari et al. (2016); } \\
\text { 2: Fabris et al. (2017) }\end{array}$ \\
\hline \multirow[t]{3}{*}{$\begin{array}{l}\text { IBH-6 (ER+, PR+, } \\
\text { HER2-) }\end{array}$} & $\begin{array}{l}\text { PRB }>\text { PRA } \\
W t\end{array}$ & WB & Nu/nu 1,2 & $\begin{array}{l}\mathrm{C}-19, \mathrm{sc}-538 \\
\text { (SC) } \\
\mathrm{H}-190 \text { (SC) }\end{array}$ & $\begin{array}{l}\text { Similar growth in E2- or } \\
\text { MPA-treated or } \\
\text { untreated mice. TAM } \downarrow^{1} \\
\text { and MFP } \uparrow \text { tumor } \\
\text { growth }{ }^{2}\end{array}$ & $\begin{array}{l}\text { 1: Bruzzone et al. } \\
\text { (2009); 2: Wargon } \\
\text { et al. (2015) }\end{array}$ \\
\hline & $\begin{array}{l}\text { PRA }>\text { PRB } \\
\text { PRA transfection }\end{array}$ & WB & $N u / n u^{1,2}$ & $\mathrm{H}-190(\mathrm{SC})$ & $\begin{array}{l}\text { MFP or TLP } \downarrow \text { tumor } \\
\text { growth } \\
\text { Others not tested }\end{array}$ & Wargon et al. (2015) \\
\hline & $\begin{array}{l}\text { PRB }>\text { PRA } \\
\text { PRB transfection }\end{array}$ & WB & $N u / n u^{1,2}$ & $\mathrm{H}-190$ (SC) & $\begin{array}{l}\text { MFP } \uparrow \text { tumor growth. TLP } \\
\text { exerted no effect }\end{array}$ & Wargon et al. (2015) \\
\hline $\begin{array}{l}\text { IBH-4 (ER+, PR+, } \\
\text { HER2-) }\end{array}$ & PRB $>$ PRA & WB & Nu/nu & $\mathrm{C}-19$ (SC) & $\begin{array}{l}\text { Similar growth in E2- or } \\
\text { MPA-treated or } \\
\text { untreated mice. TAM } \downarrow \\
\text { tumor growth. MPA } \downarrow \\
\text { E2-induced metastases }\end{array}$ & Bruzzone et al. (2009) \\
\hline $\begin{array}{l}\text { IBH-7 (ER+, PR+, } \\
\text { HER2-) }\end{array}$ & PRB $>$ PRA & WB & Nu/nu & $\mathrm{C}-19$ (SC) & $\begin{array}{l}\text { E2-dependent. MPA } \downarrow \\
\text { E2-induced metastases }\end{array}$ & Bruzzone et al. (2009) \\
\hline $\begin{array}{l}\text { BT-474 (ER+, PR+, } \\
\text { HER2+, p53 mut) }\end{array}$ & $\mathrm{NAI}$ & & & & $\begin{array}{l}\text { P4 } \uparrow \text { tumor growth, MPA } \uparrow \\
\text { metastasis }\end{array}$ & Liang et al. (2010) \\
\hline \multirow{3}{*}{$\begin{array}{l}\text { MCF-7 (ER+ PR } \\
\text { inducible, RA+, } \\
\text { GR+, HER2-P53 } \\
\text { wt) }\end{array}$} & $\begin{array}{l}\text { MCF-7 empty } \\
\text { vector }\end{array}$ & $\begin{array}{l}\text { WB (cell } \\
\text { extracts }{ }^{1} \text { ) }\end{array}$ & $\begin{array}{l}\text { NSG }{ }^{1} \\
N u / n u^{2}\end{array}$ & 1: NAI & $\begin{array}{l}\text { P4 } \downarrow \text { E2-induced tumor } \\
\text { growth } 1 \text {. ONA, MFP or P4 } \\
\downarrow \text { as TAM tumor growth } 2\end{array}$ & $\begin{array}{l}\text { 1: Mohammed et al. } \\
\text { (2015); 2: el Etreby } \\
\text { and Liang (1998) }\end{array}$ \\
\hline & MCF-7 PRA & WB & NSG & $\mathrm{NAl}$ & Slower growth than wt & $\begin{array}{l}\text { Mohammed et al. } \\
\text { (2015) }\end{array}$ \\
\hline & MCF-7PRB & WB & NSG & NAI & Slower growth than wt & $\begin{array}{l}\text { Mohammed et al. } \\
\text { (2015) }\end{array}$ \\
\hline
\end{tabular}

\#Antibody provided by Dr D Toft, Mayo Clinic, Rochester, MN; *antibody developed by authors (Estes et al., Biochemistry 26: 6250, 1987); €SC, Santa Cruz Biotech; NC, Novocastra; CS, Cell Signaling Technology; NAI, No Available Information; AR, androgen receptor; E2, 17- $\beta$-estradiol; ER, estrogen receptor; GR, glucocorticoid receptor; MFP, mifepristone; MPA, medroxyprogesterone acetate; ONA, onapristone; P4, progesterone; PR, progesterone receptor; PRA, PR isoform A; PRB, PR isoform B; TAM, tamoxifen; TLP, telapristone; WB, Western blot. 


\section{Patient-derived xenografts}

Only in few xenograft models, PR isoforms were evaluated by WB. In three out of four tumors of the WHIM xenografts, the PRB band seems stronger than the PRA band (in the publication the bands are mislabeled; the upper band is PRB and the lower band is PRA). More recently, the growth of two ER $\alpha+$, PR+ patient-derived xenografts (PDX), UCD4 and UCD65 was described (Finlay-Schultz et al. 2017). P4 and MPA similarly inhibited E2-induced tumor growth. In both cases, PRB expression was apparently higher than PRA by WB (Finlay-Schultz et al. 2017). Esber et al. (2016) showed WB data from the HBCX-19, -21, -22 and -34 PDX (Cottu et al. 2014); both PR isoforms were expressed with levels of PRB that seemed to be higher than those of PRA. The authors report a slight inhibition of tumor growth after treatment with ulipristal acetate, a selective PRs modulator, P4 or the novel antiprogestin APR19 using the HBCx-34 PDX (Table 3).

In summary, increased levels of PRB than PRA were seen in most models in which progestins showed inhibitory effects on tumor growth or metastasis. Taking into consideration that the ability to generate a PDX is by itself a bad prognostic factor (DeRose et al. 2011, Byrne et al. 2017, Shafaee \& Ellis 2017), it can be speculated that higher levels of PRB than PRA are associated with worse prognosis.

\section{PR isoforms in breast cancer cohorts}

ER $\alpha$, PR, HER2 and Ki67 are routinely evaluated as prognostic and predictive markers in breast cancer patients. According to the ER status, patients are categorized in ER $\alpha+$ $\mathrm{PR}+; \mathrm{ER} \alpha+\mathrm{PR}-; \mathrm{ER} \alpha-\mathrm{PR}+$ or $\mathrm{ER} \alpha-\mathrm{PR}-$. Whereas there is no doubt regarding the clinical benefit of measuring $E R \alpha$, the benefit of measuring PR expression is more controversial (Olivotto et al. 2004). However, as pointed out by several studies and discussed by many authors, PR expression has been proposed as a surrogate marker for ER $\alpha$ integrity and endocrine response since high total PR levels correlate with an improved tamoxifen response, longer diseasefree and overall survival (Fuqua et al. 2005, MacGrogan et al. 2005). Moreover, the $\mathrm{ER} \alpha+\mathrm{PR}-$ group has a worse prognosis, and this phenotype has been associated with impaired ER $\alpha$ function or aberrant growth factor signaling that could contribute to tamoxifen resistance (Arpino et al. 2005). On the other hand, the existence of the ER $\alpha-P R+$ group of breast cancer patients remains controversial. It has been proposed that in selected samples, either the lack of ER $\alpha$ staining or the detection of false-positive PR are related to technical issues, since in many cases which had been revisited a change in diagnosis has been registered (reviewed in Kunc et al. 2018). However, others sustain that $\mathrm{ER} \alpha-\mathrm{PR}+$ tumors represent a different subgroup with distinct molecular features and clinical course (Shen et al. 2015).

In our hands, from 352 samples with ER $\alpha$ scoring, 258 (82.10\%) were ER $\alpha+\mathrm{PR}+, 59$ (16.76\%) were ER $\alpha-\mathrm{PR}-$; $31(8.80 \%)$ were classified as $\mathrm{ER} \alpha+\mathrm{PR}-$, and only three samples were reported as $\mathrm{ER} \alpha-\mathrm{PR}+(0.09 \%)$. In all three cases, these samples displayed a PR staining $\leq 40 \%$ and PR isoforms were not detected by WB (unpublished data).

Only few studies have addressed the expression of the different PR isoforms in breast cancer (Table 4). The first study evaluating PR isoforms in breast cancers was reported in 1995 (Graham et al. 1995). They used 202 cytosols from PR+ primary tumors and analyzed the pattern of PR bands in WB. Several bands were observed; one around $115 / 120 \mathrm{kDa}$ equivalent to the PRB band of T47D cells used as controls, another ahead from the $81 \mathrm{kDa}$ band observed in the controls considered as PRA and one of $78 \mathrm{kDa}$. Extra faint bands with lower MW were occasionally observed. The median PRA/B ratio observed was 1.26.

Bamberger et al. studied a total of 53 mammary carcinomas, $21 \mathrm{PR}-$ and $32 \mathrm{PR}+$ (Bamberger et al. 2000) by WB. Band intensity was quantified as negative, weak, moderate, strong and very strong. In only two out of 32 cases, one was a recurrence, PRB showed to be increased, as compared with PRA. In this study, the authors conclude that PRB expression correlates with the absence of HER2. Overall, the authors conclude that higher PRB levels correlated with a more differentiated phenotype. The drawback is the small cohort and the fact that the authors included in the data analysis all PR+ and PR- patients.

Ariga et al. evaluated the expression of PR by IHC (Ariga et al. 2001). The samples included 47 cases of invasive ductal carcinoma, 40 ductal carcinomas in situ (DCIS), 27 atypical ductal hyperplasias and 27 cases of proliferative disease without atypia. The IHC scores for PRA in atypical ductal hyperplasias were higher than those in high histological grade DCIS or invasive carcinomas, whereas the scores for PRB were lower in invasive carcinomas with high histological grades, than in proliferative disease without atypia. Both scores correlated inversely with histological grade in invasive carcinoma and DCIS. A positive correlation between ER $\alpha$, PRA and PRB was observed in invasive carcinomas. Again, as in the previous study, the analysis was performed on PR+ and PR- samples. From the 47 cases of invasive carcinomas, 16 were PR- and $31 \mathrm{PR}+$. 
Table 3 PR isoform imbalance in breast cancer patient-derived xenograft models.

\begin{tabular}{|c|c|c|c|c|c|c|}
\hline PDX & PRA/PRB ratio & Assay & Mice & Antibodies & Effect of hormones/antagonists & References \\
\hline $\begin{array}{l}\text { PDX WHIM } \\
16 \text { skin met }\end{array}$ & PRB $>$ PRA & WB & NSG & \#8757, CS€ & E2 $\downarrow$ tumor growth & Li et al. (2013) \\
\hline $\begin{array}{l}\text { PDX WHIM } \\
18 \text { skin met }\end{array}$ & PRA $>$ PRB & WB & NSG & \#8757, CS & E2 has no effect on growth, FUL resistant & Li et al. (2013) \\
\hline $\begin{array}{l}\text { PDX WHIM } \\
20 \text { skin met }\end{array}$ & PRB $>$ PRA & WB & NSG & \#8757, CS & E2 has no effect on growth & Li et al. (2013) \\
\hline $\begin{array}{l}\text { PDX WHIM } \\
24 \text { skin met }\end{array}$ & $\mathrm{PRB}>\mathrm{PRA}$ & WB & NSG & \#8757, CS & $\mathrm{E} 2 \uparrow$ tumor growth & Li et al. (2013) \\
\hline $\begin{array}{l}\text { PDX UCD } \\
\text { UCD } 4\end{array}$ & PRB $>$ PRA & WB & NSG & $\begin{array}{l}\mathrm{H}-190(\mathrm{SC}) \\
\text { DAKO, } 1294\end{array}$ & $\begin{array}{l}\text { E2 } \uparrow \text { tumor growth; MPA or P4 } \downarrow \\
\text { E2-induced tumor growth }\end{array}$ & $\begin{array}{l}\text { Finlay-Schultz et al. } \\
\text { (2017) }\end{array}$ \\
\hline $\begin{array}{l}\text { PDX UCD } \\
\text { UCD } 65\end{array}$ & $\mathrm{PRB}>\mathrm{PRA}$ & WB & NSG & $\begin{array}{l}\text { H-190 (SC); } \\
\text { DAKO, } 1294\end{array}$ & $\begin{array}{l}\text { E2 dependent; MPA or P4 similarly } \downarrow \\
\text { E2-induced tumor growth }\end{array}$ & $\begin{array}{l}\text { Finlay-Schultz et al. } \\
\text { (2017) }\end{array}$ \\
\hline $\mathrm{HBC} \times 19$ & PRB $>$ PRA & WB & Nu/nu & $\mathrm{C}-19$ (SC) & NAI & Esber et al. (2016) \\
\hline HBCx 21 & $\mathrm{PRB}>\mathrm{PRA}$ & WB & Nu/nu & C-19 (SC) & NAI & Esber et al. (2016) \\
\hline $\mathrm{HBC} \times 22$ & $\mathrm{PRB}>\mathrm{PRA}$ & WB & Nu/nu & C-19 (SC) & NAI & Esber et al. (2016) \\
\hline $\mathrm{HBC} \times 34$ & PRB $>$ PRA & WB & Nu/nu & $\mathrm{C}-19$ (SC) & $\begin{array}{l}\text { E2 } \uparrow \text { growth. P4, APR 19, a novel } \\
\text { antiprogestin and UPA } \downarrow \text { tumor volume } \\
\text { and/or tumor weight }\end{array}$ & Esber et al. (2016) \\
\hline
\end{tabular}

ESC, Santa Cruz Biotech; NC, Novocastra; CS, Cell Signaling Technology; NAl, No Available Information; E2, 17- $\beta$-estradiol; FUL, fulvestrant; MPA, medroxyprogesterone acetate; P4, progesterone; PR, progesterone receptor; PRA, PR isoform A; PRB, PR isoform B; UPA, ulipristal acetate; WB, Western blot.

The three previous studies did not analyze the role of PRA and PRB as predictive factors for endocrine therapies. However, in 2004, Hopp et al. presented data suggesting that high PRA levels identify a subgroup of women with a poorer response to tamoxifen (Hopp et al. 2004). They evaluated frozen primary breast tumor specimens from a cohort of 297 axillary lymph node-positive patients; 119 received no adjuvant therapy after surgery and 178 were treated only with tamoxifen. Eighty-nine per cent were $\mathrm{ER} \alpha+$ and $69 \% \mathrm{PR}+$ as determined by binding techniques. Total extracts were prepared for WB. PRA and PRB levels in tumors were normalized to PRB levels in the T47Dpositive control lysate used in the same immunoblot. The primary outcome was disease-free survival. The authors reinforce the fact that it is not possible to distinguish between both isoforms by IHC and that stromal cells will not interfere with the balance between both of them. The median PRA/PRB ratio was 0.96. The PR isoforms showed a significant inverse correlation with tumor size, $\mathrm{S}$ phase and number of positive nodes. Only in the tamoxifentreated group, PRA expression higher than PRB correlated with decreased disease-free survival, suggesting that the determination of PR isoforms could help to predict tamoxifen responsiveness.

Pathiraja et al. reported an association of PRA promoter methylation with worse outcome in ER $\alpha+$ breast cancer patients (Pathiraja et al. 2011). They selected 500 patients who received tamoxifen treatment and 500 without endocrine treatment. Most of the tumors had a small size $(48 \%<2 \mathrm{~cm})$ and $66 \%$ were node negative. Of the $227 \mathrm{ER} \alpha+$, PR- tumors, PRA was methylated in $25.9 \%$ of the tumors and PRB in $28.5 \%$ suggesting loss of PRA or PRB was not a result of DNA methylation in regulatory regions of the PR genes. In the tamoxifen-treated group, overall survival was worse for patients with methylated PRA compared with non-methylated PRA. This finding conceptually contradicts the previous study (Hopp et al. 2004), since those patients with methylated PRA are supposed to be those with higher levels of PRB than PRA, and thus, better disease-free survival, although PR isoforms were not evaluated in this study.

Lindet et al. evaluated in 299 breast cancer samples the relation between mRNA expression of total $(\mathrm{PRA}+\mathrm{PRB})$ and PRB with different mRNAs of the HER/ERBB family and showed that they inversely correlated with aggressiveness (Lindet et al. 2012). Knutson et al. evaluated pSer294 expression in ten breast carcinomas. Phospho-Ser294 PRB was detected in five out of seven PR+ samples, suggesting that these tumors might be those with an active PR pathway (Knutson et al. 2012).

Mote $e t$ al. evaluated by IF the expression of both PR isoforms (Mote et al. 2015). PR expression was determined in tissue microarrays (TMAs) derived from the TransATAC cohort of patients $(n=710)$ treated either with tamoxifen or with the aromatase inhibitor anastrozole, with a 10-year median follow-up. For cohort 1, sections of archival formalin-fixed and paraffin-embedded (FFPE) tissue were stained sequentially for PRB and then PRA, using a dual 
Table 4 PR isoform ratio in breast cancer patients.

\begin{tabular}{|c|c|c|c|}
\hline Study & Assay & Antibodies & Methods \\
\hline 1 & WB & $\begin{array}{l}\text { Mix of hPRa7, } \\
\text { hPRa0 (NM€) }\end{array}$ & $\begin{array}{l}202 \text { cytosols from PR+ } \\
\text { primary tumors }\end{array}$ \\
\hline
\end{tabular}
Results
PRA and PRB bands plus an extra one
of $78 \mathrm{kDa}$. PRA/PRB ratio between 0
and 2 in $61.4 \%$, and between 0 and 4 , in $75.2 \%$ of tumors. PRA is the predominant isoform

$2 \quad W B$

NCL-PGR (NC€)

53 mammary carcinomas (21 PR-; $32 \mathrm{PR}+$ ). Band intensity quantification: negative, weak, moderate, strong, and very strong

$3 \quad$ IHC

PCR (6 cases)

hPRa7 for PRA 47 IDC* (31 PR+), 40 DCIS* and hPRa2 for PRB (NM)

$27 \mathrm{ADH}^{\#}$, and 27 PDWA** six cases were evaluated for (PRA + PRB) or PRB mRNA expression

Dual IF staining

hPRa6 for PRB 13 normal breast tissues and hPRa7 for PRA (own antibodies)

\#1294 (Dako)

qPCR (PRA + PRB) NA and PRB

\section{PRB: hPRa6}

(NM) or SAN27 (NC). PRA: hPRa7 (NM) and clone 16 (NC)

9 IHC

PRA: clone 16 (\#312; NC). PRB: clone SAN27 H.1H (NC)
(FFPE); archival FFPE blocks of 15 PDWA, $15 \mathrm{ADH}$; 15 DCIS, and 39 malignant carcinomas

297 frozen tumors from lymph node+ patients. 119: no adjuvant therapy; 178 : TAM-treated. Isoforms normalized to PRB levels of the T47D control lysate.

The primary outcome was disease-free survival

500 TAM-treated patients and 500 without treatment. All tumors were ER $\alpha+$ and $77 \%$ PR+. Most of them had small sizes and low rates of metastasis

\section{9 samples. mRNA} expression of total PR, PRB and mRNAs of the HER/ ERBB family

Tissue microarrays from the TransATAC cohort $(n=710)$ patients treated with TAM or anastrozole, (10-year median follow-up). Tumors were categorized into: PRA/PRB ratios between 0.8 and 1.2; lower than 0.8 and higher than 1.2

Archived samples from 789 women with IC were analyzed for PR isoforms. Tumors were considered as activated PR (APR)+ if they had an aggregated pattern of nuclear foci staining
In 30/32 cases, PRA $\geq$ PRB. PRB

correlated with better differentiation. The expression of both PR isoforms correlated with ER $\alpha$ expression

IHC scores for PRB were lower in high-grade IDC than in the PDWA. Positive correlation between ER $\alpha$, PRA and PRB in the IDC

IC: $51 \%$ equimolar, $10 \%$ PRB and $39 \%$ PRA predominance. Loss of control of relative PRA/PRB expression is an early event in breast cancer

PRA/PRB ratio ranged $0-31$ with $72 \%$ of the tumors showing a ratio between 0.5 and 2 . The PR isoforms showed an inverse correlation with tumor size, $\mathrm{S}$ phase, and number of positive nodes. Only in the TAMtreated group PRA > PRB correlated with decreased free survival

In $25.9 \%$ of PR-tumors, PRA was methylated. In the TAM-treated group, overall survival was worse for patients with methylated PRA. PRA is silenced in luminal breast cancer patients with worse prognosis

PR isoforms inversely correlated with differences were recorded between total PR or PRB isoform expression and HER/ERBB expression

PRA = PRB (53\%); PRA > PRB (29\%);

PRB $>$ PRA (18\%). A significant

association between PRB

predominance and previous or current use of MHT was observed. TAM-treated, but not anastrozoletreated patients had a shorter time to distant relapse if their tumors had high PRA/PRB ratios

From $79 \%$ of PR+ tumors, $25 \%$ were PRA+ and APR+, and $23 \%$ PRB+ and APR+. The APR+ score was associated with higher grade. The authors proposed this assay to select patients with aggregated PR expression as candidates for an antiprogestin treatment tumor aggressiveness. No

\section{References \\ Graham et al. \\ (1996)}

Bamberger et al. (2000)

Ariga et al.

(2001)

Mote et al. (2002)

Hopp et al. (2004)

Pathiraja et al. (2011)

Lindet et al.

(2012)

Mote et al.

(2015)

Bonneterre et al. (2016)

(Continued) http://erc.endocrinology-journals.org https://doi.org/10.1530/ERC-18-0179 (c) 2018 Society for Endocrinology Published by Bioscientifica Ltd. Printed in Great Britain 
Table 4 Continued.

$\frac{\text { Study }}{10} \frac{\text { Assay }}{\text { WB }}$

Antibodies
$\# 1294$ (Dako)
and H-190

(SC€)

11 $W B, q P C R$

8757 (Cell Signaling)

\begin{tabular}{l} 
Methods \\
\hline Nuclear and cytosolic \\
extracts from 222 frozen \\
PR+ breast cancer samples \\
were run in $8 \%$ gels for \\
electrophoresis. Samples \\
were categorized \\
according to the PRA/PRB \\
ratio Tumors were \\
equimolar (ratio: $1.2-0.83$ ), \\
PRA high (PRA-H) if PRA/ \\
PRB $\geq 1.2$ or PRB high \\
(PRB-H) if PRA/PRB $\leq 0.83$ \\
53 ER+/PR+ ductal \\
carcinomas, from the \\
Cooperative Human Tissue \\
Network. T47D cells \\
overexpressing PRA were \\
used as controls
\end{tabular}

Results

PR+ tumors: $52.3 \%$ were PRA-H and

$28.8 \%$ PRB-H. Molecular profiling

and data mining associated PRA-H

tumors with the luminal $A$ and

PRB-H with the luminal $B$ tumors.

PRB-H tumors were associated with

lower total PR values, greater tumor size, higher histological grade,

higher Ki-67 expression and HER-2

expression. $100 \%$ of PRA-H samples

$(n=19)$ were inhibited with $10 \mathrm{nM}$

MFP in tissue cultures

21 samples out of 53 showed PR

isoform bands in WB. PRA is the

prevailing isoform. A correlation

between protein and mRNA is

reported. PRA expression correlated

negatively with miR92a3p and

positively with miR-26b5p

expression. A role for PRA inhibiting

the inhibitory effect of ER on

metastases is proposed

\#ADH, Atypical Ductal Hyperplasia; *IDC, Invasive Ductal Carcinomas; **DCIS, Ductal Carcinoma In Situ; ***PDWA, Proliferative Disease Without Atypia; €NC, Novocastra; NM, Neomarkers; SC, Santa Cruz Biotech.

IC, Invasive Cancer; NA, NOT Applicable; MHT, Menopausal Hormone Treatment; ER, estrogen receptor; FFPE, formalin-fixed paraffin-embedded tissue; IHC, immunohistochemistry; MFP, mifepristone; PR, progesterone receptor; PRA, PR isoform A; PRB, PR isoform B; APR, activated PR; TAM, tamoxifen; WB, Western blot.

immunofluorescence technique, selective for PRA and $\mathrm{PRB}$, that reflects relative levels of the two isoforms (Mote et al. 1999). In FFPE samples, the antibodies used for these studies had been previously recommended by this group to recognize only PRA (Mote et al. 2001) or PRB (Clarke et al. 1987). The mean PRA/PRB ratio was determined and 138 tumors were categorized into samples with PRA/PRB ratios between 0.8 and 1.2 (equimolar; $n=73$ ); $\mathrm{PRA} / \mathrm{PRB}$ ratios lower than 0.8 (PRB predominance; $n=18$ ) and ratios higher than 1.2 (PRA predominance; $n=40$ ) in accordance with previous findings (Mote et al. 2002). A significant association between PRB predominance and previous or current use of menopausal hormone treatment was observed. Of the $16 \%(15 / 93)$ of patients who had never used menopausal treatment, almost half $(7 / 15,47 \%)$ had tumors expressing a high proportion of PRB. In addition, tamoxifen, but not anastrozole-treated patients had a significantly shorter time to distant relapse if their tumors had high mean PRA/PRB ratios, suggesting that the PRA/PRB ratio may be a discriminating factor in predicting response to these endocrine agents. The major drawback in this study is that the NCL-PGR-312 antibody used to detect PRA recognizes both PR isoforms in human xenografts (Fabris et al. 2017).

Bonnaterre and coworkers reported a novel immunohistochemical analysis to distinguish tumors

(c) 2018 Society for Endocrinology Published by Bioscientifica Ltd. Printed in Great Britain in which PR is activated (Bonneterre et al. 2016). Based on previous studies (Mote et al. 2001), they proposed two subnuclear morphological PR distribution patterns indicative of transcriptional activation status: an aggregated pattern, formed by activated ligand-bound PR disposed in nuclear foci and a diffuse pattern. The authors propose that activated PR (APR) foci/aggregates in breast cancer cells can be used as a biomarker for antiprogestin responsiveness, namely onapristone (ONA). In this study, tumors are categorized according to their 'nuclear PR pattern' and correlate it with antiestrogen treatment outcomes. PR isoforms were detected by IHC in archived 801 specimens with previously determined $\mathrm{ER} \alpha$ and PR status from women with early invasive breast cancer. APR- (APRneg) tumors are those that are either PR-, or, if they express PR, they have a diffuse staining. From 79\% of PR+ tumors, 25\% were PRA+ and APR+ and 23\% were PRB+ and APR+. The APRA+ was associated with higher histological grade. The authors propose this assay to select patients with aggregated PR expression as candidates for an antiprogestin treatment. As mentioned before, the specificity of the PRA antibody has not been corroborated (Fabris et al. 2017).

Our laboratory has recently published results from a study involving $222 \mathrm{PR}+$ breast cancer samples (Rojas et al. 2017), which were categorized according to the PRA/PRB ratio, as measured by WB. Tumors were 
A

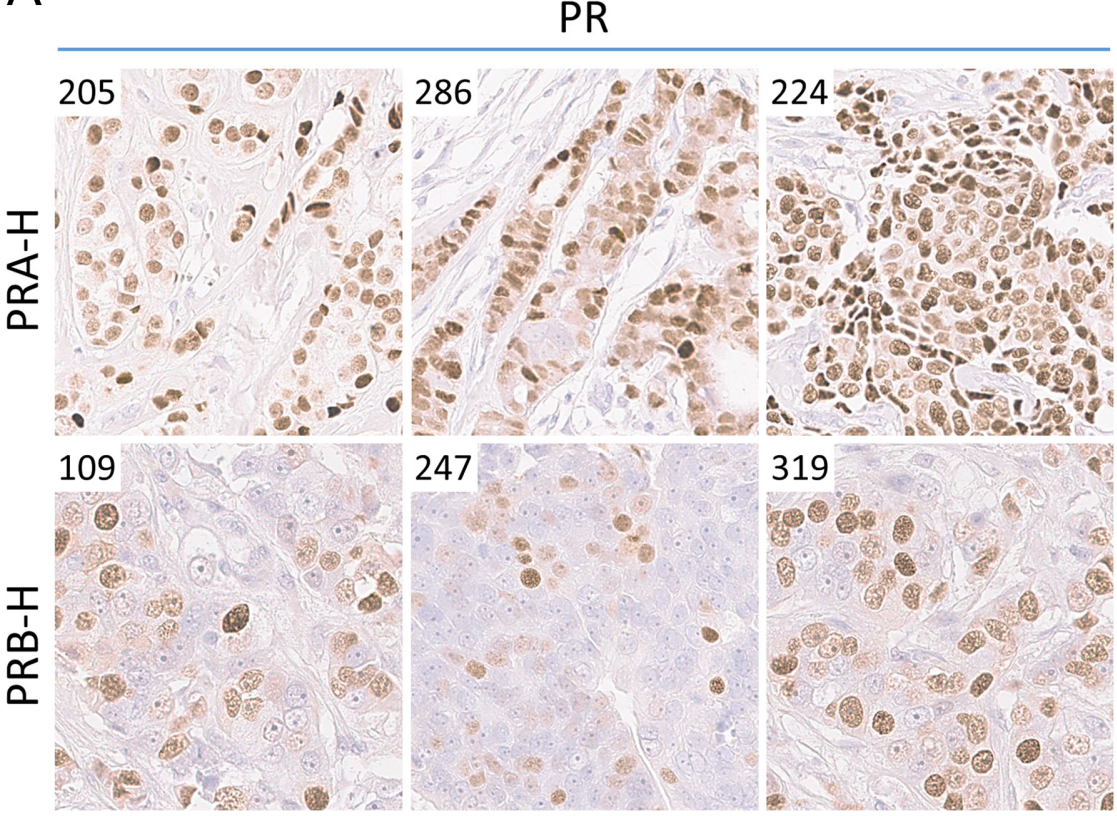

B

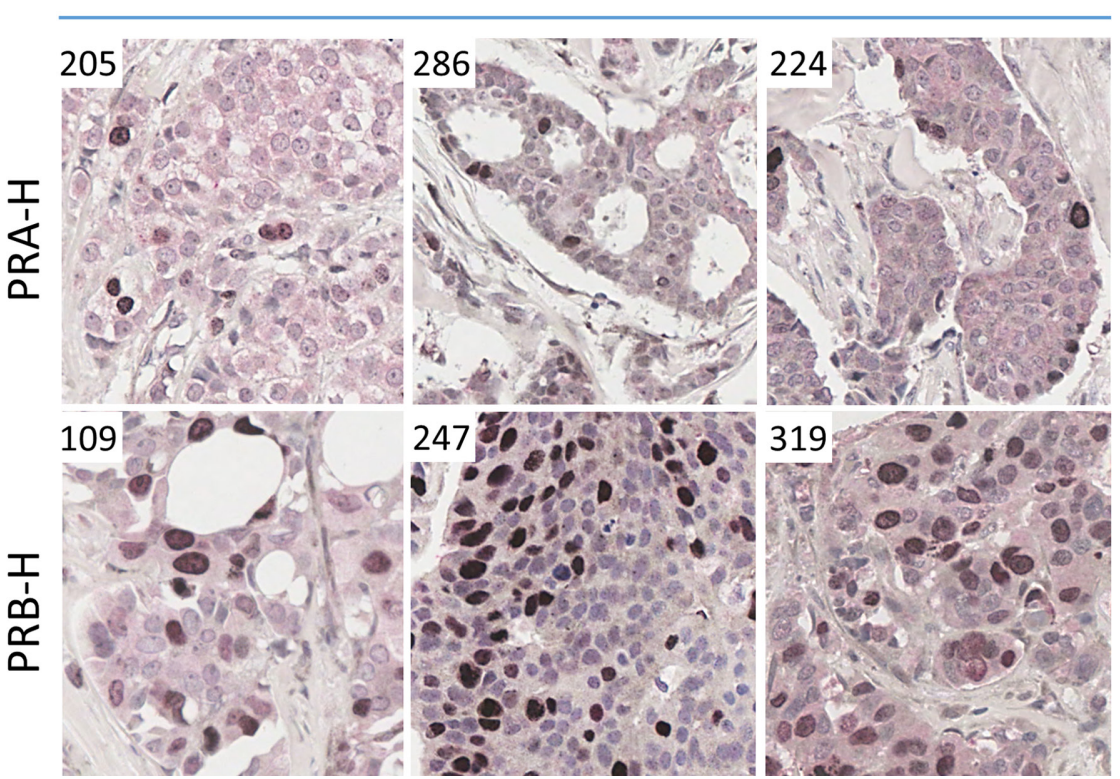

C

Tumor size $>2 \mathrm{~cm}$

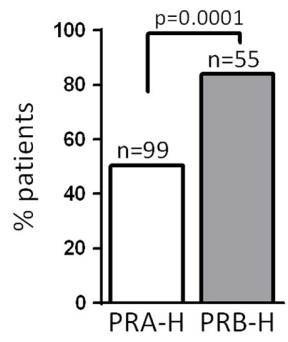

Histological grade 3

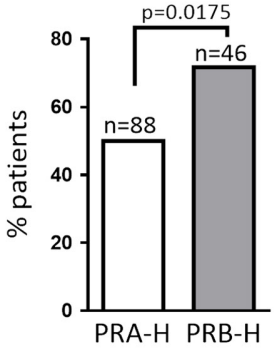

$k i 67>14 \%$

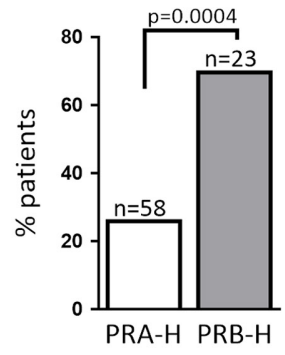

$P R>50 \%$

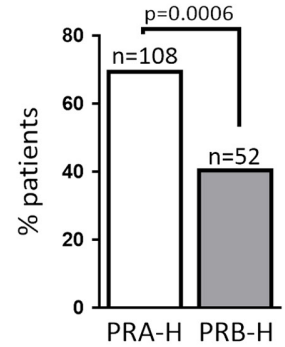

Figure 1

Quantification of clinicopathological parameters in PRA-H and PRB-H breast cancer samples. Immunohistochemical staining of PR (A) and ki67 (B) in three PRA-H and PRB-H breast cancer samples. (C) Quantification of the percentage of PRA-H or PRB-H patients with tumor sizes $>2 \mathrm{~cm}$, histological grade 3, Ki67 $>14$ or PR $>50 \%$. PR, progesterone receptor; PRA-H, breast cancer human sample with isoform A of PR/isoform B of PR $\geq 1.2 ; P R B-H$, breast cancer human sample with isoform $A$ of $P R / i s o f o r m ~ B$ of $P R \leq 0.83$. The numbers on the corners in (A) and (B) correspond to the patient sample. Statistical analysis: Fisher exact test. Data obtained from Rojas et al. (2017). A full color version of this figure is available at https://doi.org/10.1530/ ERC-18-0179. 


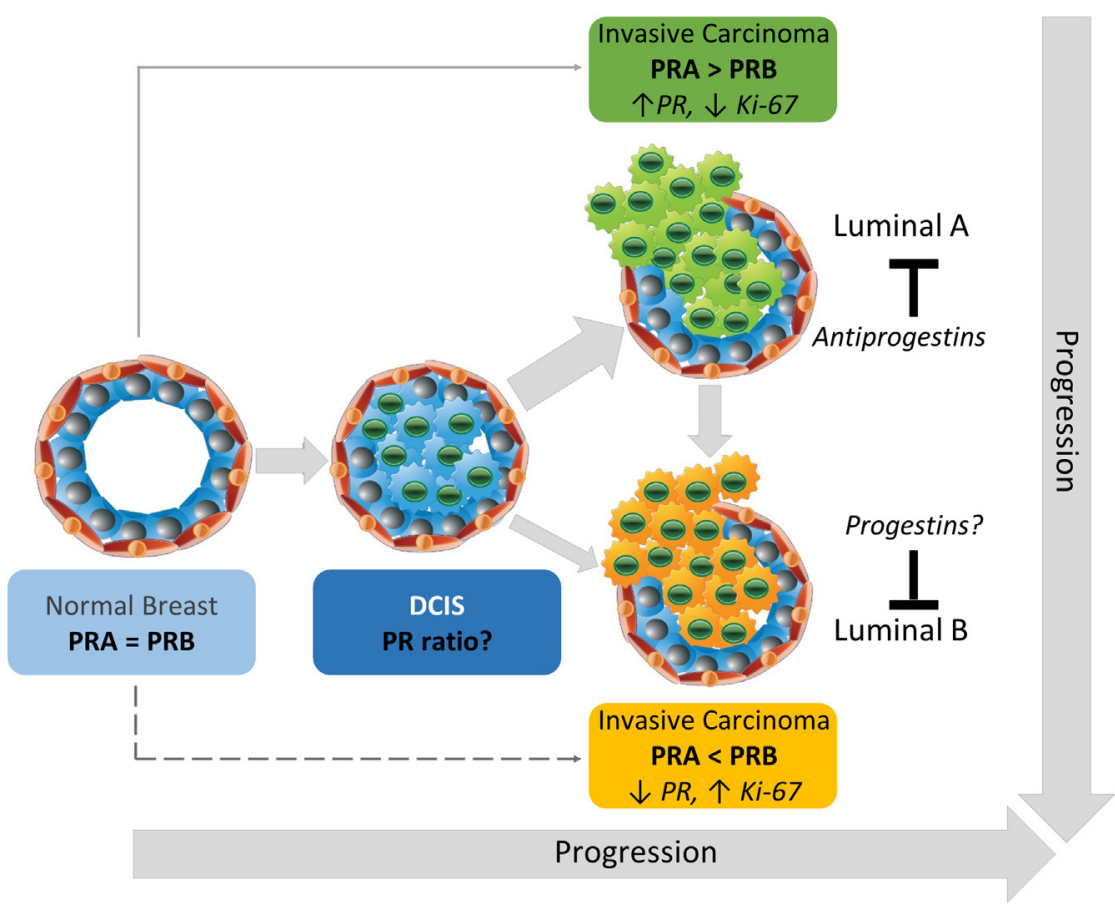

\section{Figure 2}

Schematic model of PR expression in breast cancer tumor progression. Few mammary epithelial cells express PR (equimolar PRA and PRB levels in the normal breast). Most invasive carcinomas express higher levels of PRA than PRB. PRA-H tumors recapitulate luminal A molecular subtypes (high total PR levels, low ki67 levels and respond to antiprogestin therapy). We hypothesize that invasive PRB-H tumors arise mainly during tumor progression. PRB-H tumors recapitulate luminal $B$ molecular subtypes (low total PR levels, high ki67 levels, are resistant to antiprogestin therapy and may respond to progestin therapy). Invasive carcinomas may arise from DCIS (Cowell et al. 2013) or directly from mammary stem cells (Wang et al. 2013). DCIS, ductal carcinoma in situ; PR, progesterone receptor; PRA-H, higher levels of PRA than PRB; PRB-H, higher levels of PRB than PRA. A full color version of this figure is available at https://doi. org/10.1530/ERC-18-0179. considered equimolar if the ratio was within the range 1.2-0.83 or were classified as PRA high (PRA-H) if PRA/PRB $\geq 1.2$ or PRB high (PRB-H) if PRB/PRA $\geq 1.2$. In agreement with most of previous studies, PRA-H cases were predominant: $52.3 \%$ were PRA-H and 28.8\% PRB-H, the rest being within the equimolar range. Molecular profiling and data mining of selected cases associated PRA-H tumors with the luminal A and PRB-H with the luminal B breast carcinomas. For this analysis, only ductal HER2- non-metastatic carcinomas were selected. This was corroborated by clinical parameters that associated the PRB-H with lower total PR values, greater tumor size, higher histological grade, Ki67 expression and HER-2 expression, supporting the data in molecular profiling (Fig. 1). Whereas in $100 \%$ of the PRA-H samples $(n=19)$, a decrease in Ki67 staining was observed after incubation of tissue cultures with $10 \mathrm{nM}$ MFP for $48 \mathrm{~h}$, variable responses were observed in the $10 \mathrm{PRB}-\mathrm{H}$, four equimolar or 3 PR- cases. This study is in line with that of Pathiraja et al. (2011), with observations of Knudson et al., in modified T47D cells (Knutson et al. 2012) and with our preclinical studies suggesting that PRB-H tumors may be endocrineresistant tumors (Lanari et al. 2012, Wargon et al. 2015).

Singhal et al. (2018) using the raw RNA-seq data from our study (Rojas et al. 2017) compared the list of differential genes expressed in T47D-YA and T47D-YB xenografts and those differentially regulated in PRA-H or PRB-H patients and concluded that a high PRA/PRB ratio might correlate with worse prognosis. Although the total number of samples included in both studies coincides, for the PAM50 analysis, we excluded the HER2+ cases, a lobular tumor and a metastatic tumor from a premenopausal patient, to compare a homogeneous cohort of patients. In Singhal's study, two of the HER2+ patients and the lobular patient were included, and a luminal A case of the PRA-H group was excluded. A larger cohort will be necessary to confirm these findings.

In a recent study, a positive correlation between PRA and miR26b5p expression and a negative correlation with miR92a3p was observed in 21 PRA+ breast cancer samples, with these two miRNAs being involved in the ER-PR crosstalk and in the invasive and metastatic features of luminal breast cancer (McFall et al. 2018). MiR92a expression is inversely correlated to tumor grade, positive lymph node status and recurrence-free survival in breast cancer (Nilsson et al. 2012).

In all these studies, the consensus indicates that PRA is the prevailing isoform in breast cancers; however, the role of the PRA/PRB ratio as a prognostic marker needs to be further validated in larger cohorts of breast cancer patients.

\section{Clinical trials}

Progestins (reviewed in Carroll et al. 2017) and antiprogestins (reviewed in Klijn et al. 2000, Lanari et al. 2012) have been used in the past to treat breast cancers with isolated positive responses. Among current clinical trials aimed to test the effects of antiprogestins http://erc.endocrinology-journals.org https://doi.org/10.1530/ERC-18-0179
(C) 2018 Society for Endocrinology Published by Bioscientifica Ltd. Printed in Great Britain 
or progestins in breast cancer treatment, only the MIPRA trial (NCT02651844) has included the evaluation of the PR isoform ratio as an inclusion criterion to select patients for MFP treatment during 14 days between biopsy and surgery. Only those with PRA/PRB $>1.5$ are eligible. One study uses MFP for prevention in patients carrying BRCA1 or -2 mutations with a high risk/incidence of breast and ovarian cancer (NCT01898312). As mentioned previously, $B R C A$ carriers usually have levels of PRA higher than those of PRB (Fuqua \& Cui 2004, King et al. 2004).

Other antiprogestins, such as ONA or TLP, are currently being tested. Regarding ONA (NCT02052128), although the study was expected to be completed by April 2016, the website has not been modified since June 24 , 2015. With respect to TLP, the drug is given orally once daily for 2-10 weeks between biopsy and surgical resection (NCT01800422); the status is active, not recruiting. The NCT02314156 trial will evaluate transdermal or oral TLP in $B R C A$ carriers undergoing mastectomy. The status is active, not recruiting. The NCT02408770 trial is also aimed to test the effect of antiprogestins in prevention and compares the effect of ulipristal acetate in breast density using MRI and the status is unknown.

On the other hand, a study using progestins has recently started. The NCT03306472 clinical trial is designed to evaluate the effect of letrozole alone or combined with megestrol acetate before surgery. The status is recruiting. Alternatively, the NCT00123669 trial consists of a unique dose of hydroxyprogesterone prior to surgery and the rationale is to test the effect of P4 in operable breast cancer on overall and disease-free survival at 5 years. The status is active, not recruiting.

\section{Concluding remarks}

PR ligands may stimulate or inhibit breast cancer growth, and the challenge is to determine which patient will respond to either treatment. Breast cancers with PRA/PRB ratios may respond to antiprogestin treatments, as supported by preclinical assays (Wargon et al. 2009, 2015), clinical evidence in dogs (Guil-Luna et al. 2014) and ex vivo data in human breast cancer tissue cultures (Rojas et al. 2017).

On the other hand, progestins may be inhibitory in tumors in which PRB levels are higher than those of PRA, as seen in preclinical assays (Wargon et al. 2015), in xenografted human breast cancer cell lines, and in PDX studies (Mohammed et al. 2015, Finlay-Schultz et al. 2017).

It has been suggested that most of the models in which progestins stimulate mammary carcinoma growth are biased because of the lack of ER $\alpha$ expression, as it is the case of the T47D-YA/YB models (Carroll et al. 2017) or because of the lack of estrogen supply. However, ER $\alpha$ levels in these models score higher than average ER $\alpha$ luminal breast carcinomas and experiments performed using syngeneic mice are performed under physiologic estrogen levels (Lanari et al. 2012).

Based on all the available information, malignant neoplastic transformation and the ability to invade neighboring tissues might be associated with an increased PRB activation resulting in PRB downregulation (Diep et al. 2015), inducing a switch from an equimolar stage to a preferential PRA-H stage in the human mammary gland. These tumors may be slow growing (low Ki67, luminal A) sensitive to ER $\alpha$ targeted therapy (and/or an antiprogestin treatment). As the tumor progresses and becomes insensitive to other treatments, there is an increase in cell proliferation, a decrease in total PR expression and mainly a decrease in PRA expression (which makes these tumors resistant to an antiprogestin therapy). We hypothesize that these high-grade tumors may now become sensitive to a progestin treatment (Fig. 2).

\section{Future directions}

More experimental work is necessary to better understand the role of PR isoforms in breast cancer growth and to exploit these receptors as therapeutic targets. Efforts should be geared to:

a. Design studies using homogeneous cohorts of patients to further define the PRA/PRB ratio as a prognostic factor.

b. Avoid the use of antibodies that supposedly recognize only PRA by IHC and develop specific antibodies to both PR isoforms.

c. Develop novel reliable methods to quantify the PR protein isoform ratio.

d. Determine whether there is a change in the PR isoform ratio between primary tumors and their metastatic spreads.

e. Determine whether PRA-H tumors will become PRB-H in recurrence.

f. Further explore mechanisms to re-express PRA in PRB-H tumors.

g. Design PRB selective inhibitors.

h. Dissect the role of GR and AR in the interplay with PR isoforms to design combined therapies.

i. Evaluate PR isoforms in breast cancer biopsies of patients undergoing clinical trials involving progestins/antiprogestins. 
j. Better characterize metastatic tumor models to further evaluate the role of antiprogestins/progestins as therapeutic agents in tumor progression.

\section{Declaration of interest}

The authors declare that there is no conflict of interest that could be perceived as prejudicing the impartiality of this review.

\section{Funding}

CONICET (grant PIP 2012), ANPCYT (grant PICT 2015-1022 and PIDC 2012084), Ministerio de Salud, INC (2015-C Lanari and 2015 C Lamb), Fundación para el Progreso de la Medicina (grant: GC-03).

\section{Acknowledgements}

We wish to thank Fundación Gador, Fundación IBYME, Fundación Williams, Fundación Barón and Fundación Roemmers for continuous support and to Dr Gonzalo Sequiera for the artwork of Fig. 2.

\section{References}

Abdel-Hafiz HA \& Horwitz KB 2014 Post-translational modifications of the progesterone receptors. Journal of Steroid Biochemistry and Molecular Biology 140 80-89. (https://doi.org/10.1016/j. jsbmb.2013.12.008)

Ariga N, Suzuki T, Moriya T, Kimura M, Inoue T, Ohuchi N \& Sasano H 2001 Progesterone receptor A and B isoforms in the human breast and its disorders. Japanese Journal of Cancer Research 92 302-308. (https://doi.org/10.1111/j.1349-7006.2001.tb01095.x)

Arnett-Mansfield RL, Graham JD, Hanson AR, Mote PA, Gompel A, Scurr LL, Gava N, de Fazio A \& Clarke CL 2007 Focal subnuclear distribution of progesterone receptor is ligand dependent and associated with transcriptional activity. Molecular Endocrinology 21 14-29. (https://doi.org/10.1210/me.2006-0041)

Arpino G, Weiss H, Lee AV, Schiff R, De Placido S, Osborne CK \& Elledge RM 2005 Estrogen receptor-positive, progesterone receptornegative breast cancer: association with growth factor receptor expression and tamoxifen resistance. Journal of the National Cancer Institute 97 1254-1261. (https://doi.org/10.1093/jnci/dji249)

Aupperlee M, Kariagina A, Osuch J \& Haslam SZ 2005a Progestins and breast cancer. Breast Disease 24 37-57. (https://doi.org/10.3233/ BD-2006-24104)

Aupperlee MD, Smith KT, Kariagina A \& Haslam SZ 2005b Progesterone receptor isoforms $\mathrm{A}$ and $\mathrm{B}$ : temporal and spatial differences in expression during murine mammary gland development. Endocrinology 146 3577-3588. (https://doi.org/10.1210/en.2005-0346)

Bagatell R, Khan O, Paine-Murrieta G, Taylor CW, Akinaga S \& Whitesell L 2001 Destabilization of steroid receptors by heat shock protein 90-binding drugs: a ligand-independent approach to hormonal therapy of breast cancer. Clinical Cancer Research 7 2076-2084.

Ballare C, Castellano G, Gaveglia L, Althammer S, Gonzalez-Vallinas J, Eyras E, Le Dily F, Zaurin R, Soronellas D, Vicent GP, et al. 2013 Nucleosome-driven transcription factor binding and gene regulation. Molecular Cell 49 67-79. (https://doi.org/10.1016/j. molcel.2012.10.019)

Bamberger AM, Milde-Langosch K, Schulte HM \& Loning T 2000 Progesterone receptor isoforms, PR-B and PR-A, in breast cancer: correlations with clinicopathologic tumor parameters and expression of AP-1 factors. Hormone Research 54 32-37. (https://doi. org/10.1159/000063434)

Bartosch C, Monteiro-Reis S, Vieira R, Pereira A, Rodrigues M, Jeronimo C \& Lopes JM 2015 Endometrial endometrioid carcinoma metastases show decreased ER-alpha and PR-A expression compared to matched primary tumors. PLOS ONE 10 e0134969. (https://doi. org/10.1371/journal.pone.0134969)

Bellance C, Khan JA, Meduri G, Guiochon-Mantel A, Lombes M \& Loosfelt H 2013 Progesterone receptor isoforms PRA and PRB differentially contribute to breast cancer cell migration through interaction with focal adhesion kinase complexes. Molecular Biology of the Cell 24 1363-1374. (https://doi.org/10.1091/mbc.e12-11-0807)

Bonneterre J, Bosq J, Jamme P, Valent A, Gilles EM, Zukiwski AA, Fuqua SA, Lange CA \& O'Shaughnessy J 2016 Tumour and cellular distribution of activated forms of PR in breast cancers: a novel immunohistochemical analysis of a large clinical cohort. ESMO Open 1 e000072. (https://doi.org/10.1136/esmoopen-2016-000072)

Boonyaratanakornkit V, Scott MP, Ribon V, Sherman L, Anderson SM, Maller JL, Miller WT \& Edwards DP 2001 Progesterone receptor contains a proline-rich motif that directly interacts with $\mathrm{SH} 3$ domains and activates c-Src family tyrosine kinases. Molecular Cell 8 269-280. (https://doi.org/10.1016/S1097-2765(01)00304-5)

Boonyaratanakornkit V, Bi Y, Rudd M \& Edwards DP 2008 The role and mechanism of progesterone receptor activation of extra-nuclear signaling pathways in regulating gene transcription and cell cycle progression. Steroids 73 922-928. (https://doi.org/10.1016/j. steroids.2008.01.010)

Boonyaratanakornkit V, Hamilton N, Marquez-Garban DC, Pateetin P, McGowan EM \& Pietras RJ 2018 Extranuclear signaling by sex steroid receptors and clinical implications in breast cancer. Molecular and Cellular Endocrinology 466 51-72. (https://doi.org/10.1016/j. mce.2017.11.010)

Bruzzone A, Vanzulli SI, Soldati R, Giulianelli S, Lanari C \& Luthy IA 2009 Novel human breast cancer cell lines IBH-4, IBH-6, and IBH-7 growing in nude mice. Journal of Cellular Physiology 219 477-484. (https://doi.org/10.1002/jcp.21694)

Byrne AT, Alferez DG, Amant F, Annibali D, Arribas J, Biankin AV, Bruna A, Budinska E, Caldas C, Chang DK, et al. 2017 Interrogating open issues in cancer precision medicine with patient-derived xenografts. Nature Reviews Cancer 17 254-268. (https://doi. org/10.1038/nrc.2016.140)

Carroll JS, Hickey TE, Tarulli GA, Williams M \& Tilley WD 2017 Deciphering the divergent roles of progestogens in breast cancer. Nature Reviews Cancer 17 54-64. (https://doi.org/10.1038/ nrc.2016.116)

Clarke CL, Zaino RJ, Feil PD, Miller JV, Steck ME, Ohlsson-Wilhelm BM \& Satyaswaroop PG 1987 Monoclonal antibodies to human progesterone receptor: characterization by biochemical and immunohistochemical techniques. Endocrinology 121 1123-1132. (https://doi.org/10.1210/endo-121-3-1123)

Condon JC, Hardy DB, Kovaric K \& Mendelson CR 2006 Up-regulation of the progesterone receptor (PR)-C isoform in laboring myometrium by activation of nuclear factor-kappaB may contribute to the onset of labor through inhibition of PR function. Molecular Endocrinology 20 764-775. (https://doi.org/10.1210/me.2005-0242)

Conneely OM, Mulac-Jericevic B \& Lydon JP 2003 Progesteronedependent regulation of female reproductive activity by two distinct progesterone receptor isoforms. Steroids 68 771-778. (https://doi. org/10.1016/S0039-128X(03)00126-0)

Cork DM, Lennard TW \& Tyson-Capper AJ 2008 Alternative splicing and the progesterone receptor in breast cancer. Breast Cancer Research 10 207. (https://doi.org/10.1186/bcr2097)

Cottu P, Bieche I, Assayag F, El Botty R, Chateau-Joubert S, Thuleau A, Bagarre T, Albaud B, Rapinat A, Gentien D, et al. 2014 Acquired resistance to endocrine treatments is associated with tumor-specific molecular changes in patient-derived luminal breast cancer
C) 2018 Society for Endocrinology Published by Bioscientifica Ltd. Printed in Great Britain 
xenografts. Clinical Cancer Research 20 4314-4325. (https://doi org/10.1158/1078-0432.CCR-13-3230)

Cowell CF, Weigelt B, Sakr RA, Ng CK, Hicks J, King TA \& Reis-Filho JS 2013 Progression from ductal carcinoma in situ to invasive breast cancer: revisited. Molecular Oncology 7 859-869. (https://doi. org/10.1016/j.molonc.2013.07.005)

Chabbert-Buffet N, Meduri G, Bouchard P \& Spitz IM 2005 Selective progesterone receptor modulators and progesterone antagonists: mechanisms of action and clinical applications. Human Reproduction Update 11 293-307. (https://doi.org/10.1093/humupd/dmi002)

Chan SR, Vermi W, Luo J, Lucini L, Rickert C, Fowler AM, Lonardi S, Arthur C, Young LJ, Levy DE, et al. 2012 STAT1-deficient mice spontaneously develop estrogen receptor alpha-positive luminal mammary carcinomas. Breast Cancer Research 14 R16. (https://doi. org/10.1186/bcr3100)

Cheng G, Li Y, Omoto Y, Wang Y, Berg T, Nord M, Vihko P, Warner M, Piao YS \& Gustafsson JA 2005 Differential regulation of estrogen receptor (ER)alpha and ERbeta in primate mammary gland. Journal of Clinical Endocrinology and Metabolism 90 435-444. (https://doi. org/10.1210/jc.2004-0861)

Dabydeen SA \& Furth PA 2014 Genetically engineered ERalpha-positive breast cancer mouse models. Endocrine-Related Cancer 21 R195-R208. (https://doi.org/10.1530/ERC-13-0512)

Daniel AR, Faivre EJ \& Lange CA 2007 Phosphorylation-dependent antagonism of sumoylation derepresses progesterone receptor action in breast cancer cells. Molecular Endocrinology 21 2890-2906. (https:// doi.org/10.1210/me.2007-0248)

DeRose YS, Wang G, Lin YC, Bernard PS, Buys SS, Ebbert MT, Factor R, Matsen C, Milash BA, Nelson E, et al. 2011 Tumor grafts derived from women with breast cancer authentically reflect tumor pathology, growth, metastasis and disease outcomes. Nature Medicine 17 1514-1520. (https://doi.org/10.1038/nm.2454)

Diep CH, Daniel A, Mauro L, Knutson T \& Lange C 2015 Progesterone action in breast, uterine, and ovarian cancers. Journal of Molecular Endocrinology 4 R31-R53. (https://doi.org/10.1530/JME-14-0252)

Diep CH, Ahrendt H \& Lange CA 2016 Progesterone induces progesterone receptor gene (PGR) expression via rapid activation of protein kinase pathways required for cooperative estrogen receptor alpha (ER) and progesterone receptor (PR) genomic action at ER/PR target genes. Steroids 114 48-58. (https://doi.org/10.1016/j. steroids.2016.09.004)

Dobson AD, Conneely OM, Beattie W, Maxwell BL, Mak P, Tsai MJ, Schrader WT \& O'Malley BW 1989 Mutational analysis of the chicken progesterone receptor. Journal of Biological Chemistry 264 4207-4211.

el Etreby MF \& Liang Y 1998 Effect of antiprogestins and tamoxifen on growth inhibition of MCF-7 human breast cancer cells in nude mice. Breast Cancer Research and Treatment 49 109-117. (https://doi. org/10.1023/A:1006098910000)

Esber N, Cherbonnier C, Resche-Rigon M, Hamze A, Alami M, Fagart J, Loosfelt H, Lombes M \& Chabbert-Buffet N 2016 Anti-tumoral effects of anti-progestins in a patient-derived breast cancer xenograft model. Hormones and Cancer 7 137-147. (https://doi.org/10.1007/ s12672-016-0255-4)

Fabris V, Abascal MF, Giulianelli S, May M, Sequeira GR, Jacobsen B, Lombes M, Han J, Tran L, Molinolo A, et al. 2017 Isoform specificity of progesterone receptor antibodies. Journal of Pathology: Clinical Research 3 227-233. (https://doi.org/10.1002/cjp2.83)

Faivre EJ \& Lange CA 2007 Progesterone receptors upregulate Wnt-1 to induce epidermal growth factor receptor transactivation and c-Srcdependent sustained activation of Erk1/2 mitogen-activated protein kinase in breast cancer cells. Molecular and Cellular Biology 27 466-480. (https://doi.org/10.1128/MCB.01539-06)

Faivre EJ, Daniel AR, Hillard CJ \& Lange CA 2008 Progesterone receptor rapid signaling mediates serine 345 phosphorylation and tethering to specificity protein 1 transcription factors. Molecular Endocrinology 22 823-837. (https://doi.org/10.1210/me.2007-0437)

Finlay-Schultz J, Gillen AE, Brechbuhl HM, Ivie JJ, Matthews SB, Jacobsen BM, Bentley DL, Kabos P \& Sartorius CA 2017 Breast cancer suppression by progesterone receptors is mediated by their modulation of estrogen receptors and RNA polymerase III. Cancer Research $7 \mathbf{7}$ 4934-4946. (https://doi.org/10.1158/1538-7445.AM2017-4934)

Fuqua SA \& Cui Y 2004 Estrogen and progesterone receptor isoforms: clinical significance in breast cancer. Breast Cancer Research and Treatment 87 (Supplement 1) S3-S10. (https://doi.org/10.1007/ s10549-004-1577-4)

Fuqua SA, Cui Y, Lee AV, Osborne CK \& Horwitz KB 2005 Insights into the role of progesterone receptors in breast cancer. Journal of Clinical Oncology 23 931-932; author reply 932-933. (https://doi. org/10.1200/JCO.2005.05.152)

Ghatge RP, Jacobsen BM, Schittone SA \& Horwitz KB 2005 The progestational and androgenic properties of medroxyprogesterone acetate: gene regulatory overlap with dihydrotestosterone in breast cancer cells. Breast Cancer Research 7 R1036-R1050. (https://doi. org/10.1186/bcr1340)

Goodman CR, Sato T, Peck AR, Girondo MA, Yang N, Liu C, Yanac AF, Kovatich AJ, Hooke JA, Shriver CD, et al. 2016 Steroid induction of therapy-resistant cytokeratin-5-positive cells in estrogen receptorpositive breast cancer through a BCL6-dependent mechanism. Oncogene 35 1373-1385. (https://doi.org/10.1038/onc.2015.193)

Gracanin A, de Gier J, Zegers K, Bominaar M, Rutteman GR, SchaefersOkkens AC, Kooistra HS \& Mol JA 2012 Progesterone receptor isoforms in the mammary gland of cats and dogs. Reproduction in Domestic Animals 47 (Supplement 6) 313-317. (https://doi. org/10.1111/rda.12045)

Graham JD, Yeates C, Balleine RL, Harvey SS, Milliken JS, Bilous AM \& Clarke CL 1995 Characterization of progesterone receptor A and B expression in human breast cancer. Cancer Research 55 5063-5068.

Graham JD, Yeates C, Balleine RL, Harvey SS, Milliken JS, Bilous AM \& Clarke CL 1996 Progesterone receptor A and B protein expression in human breast cancer. Journal of Steroid Biochemistry and Molecular Biology 56 93-98. (https://doi.org/10.1016/0960-0760(95)00226-X)

Graham JD, Yager ML, Hill HD, Byth K, O’Neill GM \& Clarke CL 2005 Altered progesterone receptor isoform expression remodels progestin responsiveness of breast cancer cells. Molecular Endocrinology 19 2713-2735. (https://doi.org/10.1210/me.2005-0126)

Grimm SL \& Rosen JM 2003 The role of C/EBPbeta in mammary gland development and breast cancer. Journal of Mammary Gland Biology and Neoplasia 8 191-204. (https://doi.org/10.1023/A:1025900908026)

Grimm SL, Hartig SM \& Edwards DP 2016 Progesterone receptor signaling mechanisms. Journal of Molecular Biology 428 3831-3849. (https://doi.org/10.1016/j.jmb.2016.06.020)

Guil-Luna S, Sanchez-Cespedes R, Millan Y, De Andres FJ, Rollon E, Domingo V, Guscetti F \& Martin De Las MJ 2011 Aglepristone decreases proliferation in progesterone receptor-positive canine mammary carcinomas. Journal of Veterinary Internal Medicine $\mathbf{2 5}$ 518-523. (https://doi.org/10.1111/j.1939-1676.2011.0723.x)

Guil-Luna S, Stenvang J, Brunner N, De Andres FJ, Rollon E, Domingo V, Sanchez-Cespedes R, Millan Y \& Martin De Las MJ 2014 Progesterone receptor isoform A may regulate the effects of neoadjuvant aglepristone in canine mammary carcinoma. BMC Veterinary Research 10 296. (https://doi.org/10.1186/s12917-014-0296-2)

Guil-Luna S, Millan Y, De Andres J, Rollon E, Domingo V, GarciaMacias J, Sanchez-Cespedes R \& Martin De Las MJ 2017 Prognostic impact of neoadjuvant aglepristone treatment in clinicopathological parameters of progesterone receptor-positive canine mammary carcinomas. Veterinary and Comparative Oncology 15 391-399. (https://doi.org/10.1111/vco.12175)

Guiochon-Mantel A, Delabre K, Lescop P, Perrot-Applanat M \& Milgrom E 1994 Cytoplasmic-nuclear trafficking of progesterone
(2) 2018 Society for Endocrinology Published by Bioscientifica Ltd. Printed in Great Britain 
receptor. In vivo study of the mechanism of action of antiprogestins. Biochemical Pharmacology 47 21-24. (https://doi.org/10.1016/00062952(94)90433-2)

Heneghan AF, Berton N, Miura MT \& Bain DL 2005 Self-association energetics of an intact, full-length nuclear receptor: the B-isoform of human progesterone receptor dimerizes in the micromolar range. Biochemistry 44 9528-9537. (https://doi.org/10.1021/bi050609i)

Hilton HN, Graham JD \& Clarke CL 2015 Minireview: progesterone regulation of proliferation in the normal human breast and in breast cancer: a tale of two scenarios? Molecular Endocrinology 29 1230-1242. (https://doi.org/10.1210/me.2015-1152)

Hilton HN, Clarke CL \& Graham JD 2018 Estrogen and progesterone signalling in the normal breast and its implications for cancer development. Molecular and Cellular Endocrinology 466 2-14. (https:// doi.org/10.1016/j.mce.2017.08.011)

Hopp TA, Weiss HL, Hilsenbeck SG, Cui Y, Allred DC, Horwitz KB \& Fuqua SA 2004 Breast cancer patients with progesterone receptor PR-A-rich tumors have poorer disease-free survival rates. Clinical Cancer Research 10 2751-2760. (https://doi.org/10.1158/1078-0432. CCR-03-0141)

Hovland AR, Powell RL, Takimoto GS, Tung L \& Horwitz KB 1998 An N-terminal inhibitory function, IF, suppresses transcription by the A-isoform but not the B-isoform of human progesterone receptors. Journal of Biological Chemistry 273 5455-5460. (https://doi. $\operatorname{org} / 10.1074 /$ jbc.273.10.5455)

Ibrahim YH, Byron SA, Cui X, Lee AV \& Yee D 2008 Progesterone receptor-B regulation of insulin-like growth factor-stimulated cell migration in breast cancer cells via insulin receptor substrate-2. Molecular Cancer Research 6 1491-1498. (https://doi. org/10.1158/1541-7786.MCR-07-2173)

Jacobsen BM \& Horwitz KB 2012 Progesterone receptors, their isoforms and progesterone regulated transcription. Molecular and Cellular Endocrinology 357 18-29. (https://doi.org/10.1016/j.mce.2011.09.016)

Jacobsen BM, Richer JK, Schittone SA \& Horwitz KB 2002 New human breast cancer cells to study progesterone receptor isoform ratio effects and ligand-independent gene regulation. Journal of Biological Chemistry 277 27793-27800. (https://doi.org/10.1074/jbc. M202584200)

Jacobsen BM, Schittone SA, Richer JK \& Horwitz KB 2005 Progesteroneindependent effects of human progesterone receptors (PRs) in estrogen receptor-positive breast cancer: PR isoform-specific gene regulation and tumor biology. Molecular Endocrinology 19 574-587. (https://doi.org/10.1210/me.2004-0287)

Jacobsen BM, Jambal P, Schittone SA \& Horwitz KB 2009 ALU repeats in promoters are position-dependent co-response elements (coRE) that enhance or repress transcription by dimeric and monomeric progesterone receptors. Molecular Endocrinology 23 989-1000. (https://doi.org/10.1210/me.2009-0048)

Kariagina A, Aupperlee MD \& Haslam SZ 2007 Progesterone receptor isoforms and proliferation in the rat mammary gland during development. Endocrinology 148 2723-2736. (https://doi. org/10.1210/en.2006-1493)

Kariagina A, Aupperlee MD \& Haslam SZ 2008 Progesterone receptor isoform functions in normal breast development and breast cancer. Critical Reviews in Eukaryotic Gene Expression 18 11-33. (https://doi. org/10.1615/CritRevEukarGeneExpr.v18.i1.20)

Khan JA, Bellance C, Guiochon-Mantel A, Lombes M \& Loosfelt H 2012 Differential regulation of breast cancer-associated genes by progesterone receptor isoforms PRA and PRB in a new bi-inducible breast cancer cell line. PLoS ONE 7 e45993. (https://doi.org/10.1371/ journal.pone.0045993)

King TA, Gemignani ML, Li W, Giri DD, Panageas KS, Bogomolniy F, Arroyo C, Olvera N, Robson ME, Offit K, et al. 2004 Increased progesterone receptor expression in benign epithelium of BRCA1related breast cancers. Cancer Research 64 5051-5053. (https://doi. org/10.1158/0008-5472.CAN-04-1283)
Klijn JG, Setyono-Han B \& Foekens JA 2000 Progesterone antagonists and progesterone receptor modulators in the treatment of breast cancer. Steroids 65 825-830. (https://doi.org/10.1016/S0039128X(00)00195-1)

Knutson TP, Daniel AR, Fan D, Silverstein KA, Covington KR, Fuqua SA \& Lange CA 2012 Phosphorylated and sumoylation-deficient progesterone receptors drive proliferative gene signatures during breast cancer progression. Breast Cancer Research 14 R95. (https://doi. org/10.1186/bcr3211)

Kreizman-Shefer H, Pricop J, Goldman S, Elmalah I \& Shalev E 2014 Distribution of estrogen and progesterone receptors isoforms in endometrial cancer. Diagnostic Pathology 9 77. (https://doi. org/10.1186/1746-1596-9-77)

Kunc M, Biernat W \& Senkus-Konefka E 2018 Estrogen receptor-negative progesterone receptor-positive breast cancer - 'Nobody's land' or just an artifact? Cancer Treatment Reviews 67 78-87. (https://doi. org/10.1016/j.ctrv.2018.05.005)

Lanari C, Lamb CA, Fabris VT, Helguero LA, Soldati R, Bottino MC, Giulianelli S, Cerliani JP, Wargon V \& Molinolo A 2009 The MPA mouse breast cancer model: evidence for a role of progesterone receptors in breast cancer. Endocrine-Related Cancer 16 333-350. (https://doi.org/10.1677/ERC-08-0244)

Lanari C, Wargon V, Rojas P \& Molinolo AA 2012 Antiprogestins in breast cancer treatment: are we ready? Endocrine-Related Cancer 19 R35-R50. (https://doi.org/10.1530/ERC-11-0378)

Lanari C, Alvarez M, Giulianelli S, Riggio M, Sequeira G, May M, Novaro V, Sahores A \& Lamb C 2016 The ratio of progesterone receptor isoform $A$ to $B$ determines the effect of antiprogestins on preclinical models of breast cancer metastasis. Cancer Research 76 P2-05-27. (https://doi.org/10.1158/1538-7445.SABCS15-P2-05-27)

Lange CA, Sartorius CA, Abdel-Hafiz H, Spillman MA, Horwitz KB \& Jacobsen BM 2008 Progesterone receptor action: translating studies in breast cancer models to clinical insights. Advances in Experimental Medicine and Biology 630 94-111.

Lantinga-van Leeuwen IS, van Garderen E, Rutteman GR \& Mol JA 2000 Cloning and cellular localization of the canine progesterone receptor: co-localization with growth hormone in the mammary gland. Journal of Steroid Biochemistry and Molecular Biology $\mathbf{7 5}$ 219-228. (https://doi.org/10.1016/S0960-0760(00)00173-4)

Leo JC \& Lin VC 2008 The activities of progesterone receptor isoform A and $\mathrm{B}$ are differentially modulated by their ligands in a geneselective manner. International Journal of Cancer 122 230-243. (https://doi.org/10.1002/ijc.23081)

Li S, Shen D, Shao J, Crowder R, Liu W, Prat A, He X, Liu S, Hoog J, Lu C, et al. 2013 Endocrine-therapy-resistant ESR1 variants revealed by genomic characterization of breast-cancer-derived xenografts. Cell Reports 4 1116-1130. (https://doi.org/10.1016/j. celrep.2013.08.022)

Liang Y, Besch-Williford C, Brekken RA \& Hyder SM 2007 Progestindependent progression of human breast tumor xenografts: a novel model for evaluating antitumor therapeutics. Cancer Research $\mathbf{6 7}$ 9929-9936. (https://doi.org/10.1158/0008-5472.CAN-07-1103)

Liang Y, Benakanakere I, Besch-Williford C, Hyder RS, Ellersieck MR \& Hyder SM 2010 Synthetic progestins induce growth and metastasis of BT-474 human breast cancer xenografts in nude mice. Menopause 17 1040-1047. (https://doi.org/10.1097/gme.0b013e3181d3dd0c)

Lin VC, Ng EH, Aw SE, Tan MG, Ng EH, Chan VS \& Ho GH 1999 Progestins inhibit the growth of MDA-MB-231 cells transfected with progesterone receptor complementary DNA. Clinical Cancer Research 5 395-403.

Lin VC, Ng EH, Aw SE, Tan MG \& Bay BH 2000 Progesterone induces focal adhesion in breast cancer cells MDA-MB-231 transfected with progesterone receptor complementary DNA. Molecular Endocrinology 14 348-358. (https://doi.org/10.1210/mend.14.3.0426)

Lin VC, Eng AS, Hen NE, Ng EH \& Chowdhury SH 2001 Effect of progesterone on the invasive properties and tumor growth of 
progesterone receptor-transfected breast cancer cells MDA-MB-231. Clinical Cancer Research 7 2880-2886.

Lindet C, Revillion F, Lhotellier V, Hornez L, Peyrat JP \& Bonneterre J 2012 Relationships between progesterone receptor isoforms and the HER/ErbB receptors and ligands network in 299 primary breast cancers. International Journal of Biological Markers 27 e111-e117. (https://doi.org/10.5301/JBM.2012.9198)

MacGrogan G, de Mascarel I, Sierankowski G, Mauriac L, Debled M, Durand M, De Lara CT, Avril A, Picot V \& Mathoulin-Pelissier S 2005 Time for reappraisal of progesterone-receptor testing in breast cancer management. Journal of Clinical Oncology 23 2870-2871; author reply 2871. (https://doi.org/10.1200/JCO.2005.05.241)

McDonnell DP \& Goldman ME 1994 RU486 exerts antiestrogenic activities through a novel progesterone receptor A form-mediated mechanism. Journal of Biological Chemistry 269 11945-11949.

McFall T, Patki M, Rosati R \& Ratnam M 2015 Role of the short isoform of the progesterone receptor in breast cancer cell invasiveness at estrogen and progesterone levels in the pre- and post-menopausal ranges. Oncotarget 6 33146-33164. (https://doi.org/10.18632/ oncotarget.5082)

McFall T, McKnight B, Rosati R, Kim S, Huang Y, Viola-Villegas N \& Ratnam M 2018 Progesterone receptor A promotes invasiveness and metastasis of luminal breast cancer by suppressing regulation of critical microRNAs by estrogen. Journal of Biological Chemistry 293 1163-1177. (https://doi.org/10.1074/jbc.M117.812438)

McGowan EM \& Clarke CL 1999 Effect of overexpression of progesterone receptor $\mathrm{A}$ on endogenous progestin-sensitive endpoints in breast cancer cells. Molecular Endocrinology 13 1657-1671. (https://doi.org/10.1210/mend.13.10.0356)

McGowan EM, Weinberger RP, Graham JD, Hill HD, Hughes JA, O’Neill GM \& Clarke CL 2003 Cytoskeletal responsiveness to progestins is dependent on progesterone receptor A levels. Journal of Molecular Endocrinology 31 241-253. (https://doi.org/10.1677/ jme.0.0310241)

McGowan EM, Saad S, Bendall LJ, Bradstock KF \& Clarke CL 2004 Effect of progesterone receptor a predominance on breast cancer cell migration into bone marrow fibroblasts. Breast Cancer Research and Treatment 83 211-220. (https://doi. org/10.1023/B:BREA.0000014041.58977.80)

McGowan EM, Russell AJ, Boonyaratanakornkit V, Saunders DN, Lehrbach GM, Sergio CM, Musgrove EA, Edwards DP \& Sutherland RL 2007 Progestins reinitiate cell cycle progression in antiestrogen-arrested breast cancer cells through the B-isoform of progesterone receptor. Cancer Research 67 8942-8951. (https://doi. org/10.1158/0008-5472.CAN-07-1255)

Millanta F, Calandrella M, Bari G, Niccolini M, Vannozzi I \& Poli A 2005 Comparison of steroid receptor expression in normal, dysplastic, and neoplastic canine and feline mammary tissues. Research in Veterinary Science 79 225-232. (https://doi.org/10.1016/j.rvsc.2005.02.002)

Mohammed H, Russell IA, Stark R, Rueda OM, Hickey TE, Tarulli GA, Serandour AA, Birrell SN, Bruna A, Saadi A, et al. 2015 Progesterone receptor modulates ERalpha action in breast cancer. Nature 523 313-317. (https://doi.org/10.1038/nature14583)

Montero GG, Vanzulli SI, Cerliani JP, Bottino MC, Bolado J, Vela J, BecuVillalobos D, Benavides F, Gutkind S, Patel V, et al. 2007 Association of estrogen receptor alpha and progesterone receptor A expression with hormonal mammary carcinogenesis: role of the host microenvironment. Breast Cancer Research 9 R22. (https://doi. org/10.1186/bcr1660)

Mote PA, Balleine RL, McGowan EM \& Clarke CL 1999 Colocalization of progesterone receptors A and B by dual immunofluorescent histochemistry in human endometrium during the menstrual cycle. Journal of Clinical Endocrinology and Metabolism 84 2963-2971. (https://doi.org/10.1210/jcem.84.8.5928)

Mote PA, Johnston JF, Manninen T, Tuohimaa P \& Clarke CL 2001 Detection of progesterone receptor forms A and B by immunohistochemical analysis. Journal of Clinical Pathology 54 624-630. (https://doi.org/10.1136/jcp.54.8.624)

Mote PA, Bartow S, Tran N \& Clarke CL 2002 Loss of co-ordinate expression of progesterone receptors A and B is an early event in breast carcinogenesis. Breast Cancer Research and Treatment 72 163-172. (https://doi.org/10.1023/A:1014820500738)

Mote PA, Gompel A, Howe C, Hilton HN, Sestak I, Cuzick J, Dowsett M, Hugol D, Forgez P, Byth K, et al. 2015 Progesterone receptor A predominance is a discriminator of benefit from endocrine therapy in the ATAC trial. Breast Cancer Research and Treatment 151 309-318. (https://doi.org/10.1007/s10549-015-3397-0)

Mueck AO, Ruan X, Seeger H, Fehm T \& Neubauer H 2014 Genomic and non-genomic actions of progestogens in the breast. Journal of Steroid Biochemistry and Molecular Biology 142 62-67. (https://doi. org/10.1016/j.jsbmb.2013.08.011)

Musgrove EA, Lee CS \& Sutherland RL 1991 Progestins both stimulate and inhibit breast cancer cell cycle progression while increasing expression of transforming growth factor alpha, epidermal growth factor receptor, c-fos, and c-myc genes. Molecular and Cellular Biology 11 5032-5043. (https://doi.org/10.1128/MCB.11.10.5032)

Nilsson S, Moller C, Jirstrom K, Lee A, Busch S, Lamb R \& Landberg G 2012 Downregulation of miR-92a is associated with aggressive breast cancer features and increased tumour macrophage infiltration. PLoS ONE 7 e36051. (https://doi.org/10.1371/journal.pone.0036051)

Olivotto IA, Truong PT, Speers CH, Bernstein V, Allan SJ, Kelly SJ \& Lesperance ML 2004 Time to stop progesterone receptor testing in breast cancer management. Journal of Clinical Oncology 22 1769-1770. (https://doi.org/10.1200/JCO.2004.99.251)

Patel B, Elguero S, Thakore S, Dahoud W, Bedaiwy M \& Mesiano S 2015 Role of nuclear progesterone receptor isoforms in uterine pathophysiology. Human Reproduction Update 21 155-173. (https:// doi.org/10.1093/humupd/dmu056)

Pathiraja TN, Shetty PB, Jelinek J, He R, Hartmaier R, Margossian AL, Hilsenbeck SG, Issa JP \& Oesterreich S 2011 Progesterone receptor isoform-specific promoter methylation: association of PRA promoter methylation with worse outcome in breast cancer patients. Clinical Cancer Research 17 4177-4186. (https://doi.org/10.1158/1078-0432. CCR-10-2950)

Poole AJ, Li Y, Kim Y, Lin SC, Lee WH \& Lee EY 2006 Prevention of Brca1-mediated mammary tumorigenesis in mice by a progesterone antagonist. Science 314 1467-1470. (https://doi.org/10.1126/ science.1130471)

Presman DM, Ganguly S, Schiltz RL, Johnson TA, Karpova TS \& Hager GL 2016 DNA binding triggers tetramerization of the glucocorticoid receptor in live cells. PNAS 113 8236-8241. (https:// doi.org/10.1073/pnas.1606774113)

Qiu M \& Lange CA 2003 MAP kinases couple multiple functions of human progesterone receptors: degradation, transcriptional synergy, and nuclear association. Journal of Steroid Biochemistry and Molecular Biology 85 147-157. (https://doi.org/10.1016/S0960-0760(03)00221-8)

Renthal NE, Williams KC, Montalbano AP, Chen CC, Gao L \& Mendelson CR 2015 Molecular regulation of parturition: a myometrial perspective. Cold Spring Harbor Perspectives in Medicine 5 a023069. (https://doi.org/10.1101/cshperspect.a023069)

Richer JK, Jacobsen BM, Manning NG, Abel MG, Wolf DM \& Horwitz KB 2002 Differential gene regulation by the two progesterone receptor isoforms in human breast cancer cells. Journal of Biological Chemistry 277 5209-5218. (https://doi.org/10.1074/jbc.M110090200)

Rojas PA, May M, Sequeira GR, Elia A, Alvarez M, Martinez P, Gonzalez P, Hewitt S, He X, Perou CM, et al. 2017 Progesterone receptor isoform ratio: a breast cancer prognostic and predictive factor for antiprogestin responsiveness. Journal of the National Cancer Institute 109 djw317. (https://doi.org/10.1093/jnci/djw317)

Sampayo R, Recouvreux S \& Simian M 2013 The hyperplastic phenotype in PR-A and PR-B transgenic mice: lessons on the role of estrogen and progesterone receptors in the mouse mammary gland and breast 
cancer. Vitamins and Hormones 93 185-201. (https://doi.org/10.1016/ B978-0-12-416673-8.00012-5)

Sartorius CA, Groshong SD, Miller LA, Powell RL, Tung L, Takimoto GS \& Horwitz KB 1994a New T47D breast cancer cell lines for the independent study of progesterone B- and A-receptors: only antiprogestin-occupied B-receptors are switched to transcriptional agonists by cAMP. Cancer Research $\mathbf{5 4} 3868-3877$.

Sartorius CA, Melville MY, Hovland AR, Tung L, Takimoto GS \& Horwitz KB 1994b A third transactivation function (AF3) of human progesterone receptors located in the unique $\mathrm{N}$-terminal segment of the B-isoform. Molecular Endocrinology 8 1347-1360. (https://doi. org/10.1210/mend.8.10.7854352)

Sartorius CA, Shen T \& Horwitz KB 2003 Progesterone receptors A and B differentially affect the growth of estrogen-dependent human breast tumor xenografts. Breast Cancer Research and Treatment 79 287-299. (https://doi.org/10.1023/A:1024031731269)

Scarpin KM, Graham JD, Mote PA \& Clarke CL 2009 Progesterone action in human tissues: regulation by progesterone receptor (PR) isoform expression, nuclear positioning and coregulator expression. Nuclear Receptor Signaling 7 e009. (https://doi.org/10.1621/nrs.07009)

Schneider W, Ramachandran C, Satyaswaroop PG \& Shyamala G 1991 Murine progesterone receptor exists predominantly as the 83-kilodalton ' $\mathrm{A}$ ' form. Journal of Steroid Biochemistry and Molecular Biology 38 285-291. (https://doi.org/10.1016/0960-0760(91)90099-Q)

Schoonen WG, Dijkema R, de Ries RJ, Wagenaars JL, Joosten JW, de Gooyer ME, Deckers GH \& Kloosterboer HJ 1998 Human progesterone receptor $\mathrm{A}$ and $\mathrm{B}$ isoforms in $\mathrm{CHO}$ cells. II. Comparison of binding, transactivation and ED50 values of several synthetic (anti)progestagens in vitro in CHO and MCF-7 cells and in vivo in rabbits and rats. Journal of Steroid Biochemistry and Molecular Biology 64 157-170. (https://doi.org/10.1016/S0960-0760(97)00161-1)

Shafaee MN \& Ellis MJ 2017 Breast cancer patient-derived xenografts: pros, cons, and next steps. Journal of the National Cancer Institute 109 djw307. (https://doi.org/10.1093/jnci/djw307)

Shen T, Horwitz KB \& Lange CA 2001 Transcriptional hyperactivity of human progesterone receptors is coupled to their ligand-dependent down-regulation by mitogen-activated protein kinase-dependent phosphorylation of serine 294. Molecular and Cellular Biology 21 6122-6131. (https://doi.org/10.1128/MCB.21.18.6122-6131.2001)

Shen T, Brandwein-Gensler M, Hameed O, Siegal GP \& Wei S 2015 Characterization of estrogen receptor-negative/progesterone receptorpositive breast cancer. Human Pathology 46 1776-1784. (https://doi. org/10.1016/j.humpath.2015.07.019)

Shyamala G, Yang X, Cardiff RD \& Dale E 2000 Impact of progesterone receptor on cell-fate decisions during mammary gland development. PNAS 97 3044-3049. (https://doi.org/10.1073/pnas.97.7.3044)

Singhal H, Greene ME, Tarulli G, Zarnke AL, Bourgo RJ, Laine M, Chang YF, Ma S, Dembo AG, Raj GV, et al. 2016 Genomic agonism and phenotypic antagonism between estrogen and progesterone receptors in breast cancer. Science Advances 2 e1501924. (https://doi. org/10.1126/sciadv.1501924)

Singhal H, Greene ME, Zarnke AL, Laine M, Al Abosy R, Chang YF, Dembo AG, Schoenfelt K, Vadhi R, Qiu X, et al. 2018 Progesterone receptor isoforms, agonists and antagonists differentially reprogram estrogen signaling. Oncotarget 9 4282-4300. (https://doi. org/10.18632/oncotarget.21378)

Skildum A, Faivre E \& Lange CA 2005 Progesterone receptors induce cell cycle progression via activation of mitogen-activated protein kinases. Molecular Endocrinology 19 327-339. (https://doi.org/10.1210/ me.2004-0306)
Taylor D, Pearce CL, Hovanessian-Larsen L, Downey S, Spicer DV, Bartow S, Pike MC, Wu AH \& Hawes D 2009 Progesterone and estrogen receptors in pregnant and premenopausal non-pregnant normal human breast. Breast Cancer Research and Treatment 118 161-168. (https://doi.org/10.1007/s10549-009-0322-4)

Tung L, Abdel-Hafiz H, Shen T, Harvell DM, Nitao LK, Richer JK, Sartorius CA, Takimoto GS \& Horwitz KB 2006 Progesterone receptors (PR)-B and -A regulate transcription by different mechanisms: AF-3 exerts regulatory control over coactivator binding to PR-B. Molecular Endocrinology 20 2656-2670. (https://doi. org/10.1210/me.2006-0105)

Vazquez SM, Mladovan A, Garbovesky C, Baldi A \& Luthy IA 2004 Three novel hormone-responsive cell lines derived from primary human breast carcinomas: functional characterization. Journal of Cellular Physiology 199 460-469. (https://doi.org/10.1002/jcp.10466)

Wang RA, Li ZS, Zhang HZ, Zheng PJ, Li QL, Shi JG, Yan QG, Ye J, Wang JB, Guo Y, et al. 2013 Invasive cancers are not necessarily from preformed in situ tumours - an alternative way of carcinogenesis from misplaced stem cells. Journal of Cellular and Molecular Medicine 17 921-926. (https://doi.org/10.1111/jcmm.12078)

Wargon V, Helguero LA, Bolado J, Rojas P, Novaro V, Molinolo A \& Lanari C 2009 Reversal of antiprogestin resistance and progesterone receptor isoform ratio in acquired resistant mammary carcinomas. Breast Cancer Research and Treatment 116 449-460. (https://doi. org/10.1007/s10549-008-0150-y)

Wargon V, Fernandez SV, Goin M, Giulianelli S, Russo J \& Lanari C 2011 Hypermethylation of the progesterone receptor A in constitutive antiprogestin-resistant mouse mammary carcinomas. Breast Cancer Research and Treatment 126 319-332. (https://doi.org/10.1007/ s10549-010-0908-x)

Wargon V, Riggio M, Giulianelli S, Sequeira GR, Rojas P, May M, Polo ML, Gorostiaga MA, Jacobsen B, Molinolo A, et al. 2015 Progestin and antiprogestin responsiveness in breast cancer is driven by the PRA/PRB ratio via AIB1 or SMRT recruitment to the CCND1 and MYC promoters. International Journal of Cancer 136 2680-2692. (https://doi.org/10.1002/ijc.29304)

Wei LL, Gonzalez-Aller C, Wood WM, Miller LA \& Horwitz KB 1990 5 '-Heterogeneity in human progesterone receptor transcripts predicts a new amino-terminal truncated ' $\mathrm{C}$ '-receptor and unique A-receptor messages. Molecular Endocrinology 4 1833-1840. (https://doi. org/10.1210/mend-4-12-1833)

Wen DX, Xu YF, Mais DE, Goldman ME \& McDonnell DP 1994 The A and $\mathrm{B}$ isoforms of the human progesterone receptor operate through distinct signaling pathways within target cells. Molecular and Cellular Biology 14 8356-8364. (https://doi.org/10.1128/ MCB.14.12.8356)

Wu J, Richer J, Horwitz KB \& Hyder SM 2004 Progestin-dependent induction of vascular endothelial growth factor in human breast cancer cells: preferential regulation by progesterone receptor B. Cancer Research 64 2238-2244. (https://doi.org/10.1158/0008-5472. CAN-03-3044)

Yeates C, Hunt SM, Balleine RL \& Clarke CL 1998 Characterization of a truncated progesterone receptor protein in breast tumors. Journal of Clinical Endocrinology and Metabolism 83 4600-4467. (https://doi. org/10.1210/jcem.83.2.4531)

Zhang X, Podsypanina K, Huang S, Mohsin SK, Chamness GC, Hatsell S, Cowin P, Schiff R \& Li Y 2005 Estrogen receptor positivity in mammary tumors of Wnt- 1 transgenic mice is influenced by collaborating oncogenic mutations. Oncogene 24 4220-4231. (https:// doi.org/10.1038/sj.onc.1208597)

Received in final form 4 July 2018

Accepted 9 July 2018

Accepted Preprint published online 10 July 2018
(2) 2018 Society for Endocrinology Published by Bioscientifica Ltd. Printed in Great Britain 